\title{
Peptide Inhibitors of Kv1.5: An Option for the Treatment of Atrial Fibrillation
}

\author{
Jesús Borrego $^{1}$, Adam Feher ${ }^{1}\left(\mathbb{D}\right.$, Norbert Jost ${ }^{2,3,4}\left(\mathbb{D}\right.$, Gyorgy Panyi $^{1}\left(\mathbb{D}\right.$, Zoltan Varga $^{1}$ and Ferenc Papp $^{1, *(\mathbb{D})}$ \\ 1 Department of Biophysics and Cell Biology, Faculty of Medicine, University of Debrecen, Egyetem ter 1, \\ H-4032 Debrecen, Hungary; jesus.borrego@med.unideb.hu (J.B.); feher.adam@med.unideb.hu (A.F.); \\ panyi@med.unideb.hu (G.P.); veze@med.unideb.hu (Z.V.) \\ 2 Department of Pharmacology and Pharmacotherapy, Faculty of Medicine, University of Szeged, \\ 6725 Szeged, Hungary; jost.norbert@med.u-szeged.hu \\ 3 Department of Pharmacology and Pharmacotherapy, Interdisciplinary Excellence Centre, \\ University of Szeged, 6725 Szeged, Hungary \\ 4 ELKH-SZTE Research Group for Cardiovascular Pharmacology, Eötvös Loránd Research Network, \\ 6725 Szeged, Hungary \\ * Correspondence: papp.ferenc@med.unideb.hu
}

Citation: Borrego, J.; Feher, A.; Jost, N.; Panyi, G.; Varga, Z.; Papp, F. Peptide Inhibitors of Kv1.5: An Option for the Treatment of Atrial Fibrillation. Pharmaceuticals 2021, 14, 1303. https://doi.org/10.3390/ ph14121303

Academic Editors: Arpad Szallasi, Balazs Horvath and Péter P. Nánási

Received: 26 October 2021

Accepted: 9 December 2021

Published: 14 December 2021

Publisher's Note: MDPI stays neutral with regard to jurisdictional claims in published maps and institutional affiliations.

Copyright: (c) 2021 by the authors. Licensee MDPI, Basel, Switzerland. This article is an open access article distributed under the terms and conditions of the Creative Commons Attribution (CC BY) license (https:/ / creativecommons.org/licenses/by/ $4.0 /)$.

\begin{abstract}
The human voltage gated potassium channel Kv1.5 that conducts the $\mathrm{I}_{\mathrm{Kur}}$ current is a key determinant of the atrial action potential. Its mutations have been linked to hereditary forms of atrial fibrillation (AF), and the channel is an attractive target for the management of AF. The development of $\mathrm{I}_{\text {Kur }}$ blockers to treat AF resulted in small molecule Kv1.5 inhibitors. The selectivity of the blocker for the target channel plays an important role in the potential therapeutic application of the drug candidate: the higher the selectivity, the lower the risk of side effects. In this respect, small molecule inhibitors of Kv1.5 are compromised due to their limited selectivity. A wide range of peptide toxins from venomous animals are targeting ion channels, including mammalian channels. These peptides usually have a much larger interacting surface with the ion channel compared to small molecule inhibitors and thus, generally confer higher selectivity to the peptide blockers. We found two peptides in the literature, which inhibited $\mathrm{I}_{\text {Kur }}$ : Ts6 and Osu1. Their affinity and selectivity for Kv1.5 can be improved by rational drug design in which their amino acid sequences could be modified in a targeted way guided by in silico docking experiments.
\end{abstract}

Keywords: Kv1.5; $\mathrm{I}_{\text {Kur; }}$ peptide inhibitor; atrial fibrillation

\section{Introduction}

Ion channels are transmembrane proteins, which form a pore in the cell membrane for ions to pass through. Several classifications of ion channels are known, for example, based on selectivity, gating or amino acid sequence. The gating mechanism can be of many types, such as voltage, stretch, ligand or temperature. Voltage-gated ion channels (VGICs) form one of the largest groups. These ion channels are involved in a great variety of cellular functions, such as generation of action potentials (AP) in excitable cells or activation in numerous non-excitable cell types, such as lymphocytes and tumor cells. VGICs typically consist of four subunits (potassium channels) or four domains (calcium and sodium channels), each of which is made up of six transmembrane helices (S1-S6). The first four helices together (S1-S4) are called the voltage-sensing domain (VSD), while the rest (S5-S6) build up the pore (Figure 1). The voltage sensing response mostly comes from the movement of S4, which has net positive electric charge, originating from positively charged amino acids: arginines and lysines. In response to a membrane potential change, these proteins open their ion-selective pore through which ions move passively across the membrane, driven by the electro-chemical potential difference [1-4]. The discovery of voltage-sensing phosphatase (VSP) and the voltage-activated proton channel (Hv1) revealed that the VSD can exist independently from the ion-conducting pore [5-7]. 


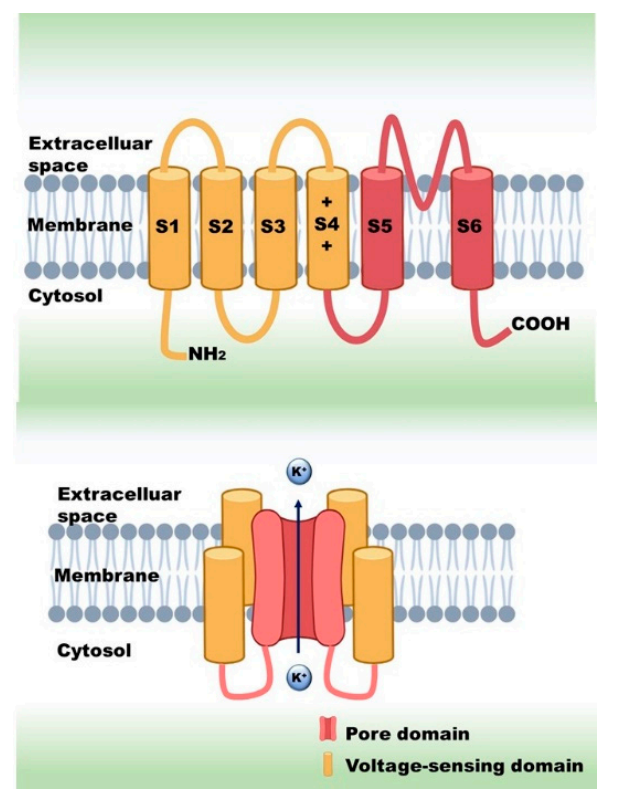

Figure 1. Stucture of voltage-gated potassium channels.

Among VGICs, the voltage-gated potassium channels (Kv) form a large family with some 40 members [8]. They are highly selective for potassium ions over other cations and expressed in almost all cell types, including muscle cells, neurons and immune cells, playing active roles in a variety of cellular functions. $\mathrm{Kv}$ channels provide the outward cation currents required to terminate the AP in excitable cells and allow the membrane potential to return to a negative resting potential following an AP. Several $\mathrm{Kv}$ channels contribute to shaping of the AP in the heart. The currents produced by these channels in cardiomyocytes include: the "transient outward" potassium current $\left(\mathrm{I}_{\mathrm{to} 1}\right)$; the delayed rectifier potassium channel currents, which are named based on the speed at which they activate: slowly activating $\left(\mathrm{I}_{\mathrm{Ks}}\right)$, rapidly activating $\left(\mathrm{I}_{\mathrm{Kr}}\right)$ and ultra-rapidly activating $\left(\mathrm{I}_{\mathrm{Kur}}\right)$ [9]. $\mathrm{I}_{\mathrm{Kur}}$ is generated by the potassium current through the Kv1.5 channel. $\mathrm{I}_{\mathrm{Kur}}$ is present in human atrial myocytes but not in the human ventricle [10]. Many studies have concluded that inhibition of $\mathrm{I}_{\mathrm{Kur}}$ could prolong the AP duration (APD) of atrial fibrillation patients [11,12], and by this, it can terminate the fibrillation, indicating that Kv1.5 is a potential target for atrial fibrillation therapy [13-17].

\section{Diseases Related to Kv1.5}

The most well-known channelopathy associated with the Kv1.5 channel is atrial fibrillation (AF). Today, a plethora of mutations have already been identified as causes of AF. Among them there are loss of function (LOF) mutations (E375X, Y155C, D469E and $\mathrm{P} 488 \mathrm{~S}$ ), which make the atrial action potential (AP) prolonged, and gain of function (GOF) mutations (E48G, A305T and D332H), which shorten the AP. In the former case, the prolongation of the AP and the effective refractory period (ERP) increases the probability of early afterdepolarizations (EADs). However, during GOF mutations, the shortening of the ERP will increase the excitability of the atrial tissue as a potential mechanism behind AF $[18,19]$.

Besides atrial fibrillation, mutations of the Kv1.5 channel gene can result in various diseases. Remillard and colleagues identified 17 single-nucleotide polymorphisms of the Kv1.5 gene in pulmonary arterial hypertension (PAH) patients [20], which may contribute to the downregulation of KCNA5, causing the increase of the vascular tone. Fu and colleagues [21] found that in intrauterine growth retardation, while Kv1.5 expression was decreased, the tyrosine-phosphorylation of these channels was significantly increased. This process led to the proliferation of the pulmonary artery smooth muscle cells, which eventually resulted in the thickening of the pulmonary arterial wall, i.e., PAH. MacFarlane 
and Sontheimer [22] showed in astrocytes that Kv1.5 is associated with Src family protein tyrosine kinases, which are responsible for astrocyte proliferation. This connection between Kv1.5 and astrocyte proliferation stimulated numerous tumor-related studies. Preussat and colleagues [23] found high Kv1.5 expression in human gliomas, which was the most prominent in astrocytomas, moderate in oligodendrogliomas and low in glioblastomas. Bielanska and colleagues pointed out that in stomach, pancreatic and breast cancer, the high expression of Kv1.5 was due to the presence of infiltrating inflammatory cells [24]. However, in bladder, skin, ovary and lymph node cancers, Kv1.5 was highly expressed in the tumorigenic cells. According to Vallejo-Gracia and colleagues [25], Kv1.5 expression shows an inverse correlation with lymphoma aggressiveness; therefore, the level of this protein can be useful in prognosis, treatment and outcome prediction as well.

\section{Atrial Fibrillation and Possible Pharmacological Treatments}

$\mathrm{AF}$ is characterized by an irregular and often rapid heart rate. In people with $\mathrm{AF}$, blood flow is significantly slowed in the atria, which may cause blood to pool, greatly increasing the chances of blood clot formation. When a piece of a clot breaks off, it can travel to the brain and cause a stroke, which is one of the most serious consequences of AF. However, blood clots may circulate to other organs as well, blocking blood flow and causing ischemia. AF is the most common serious abnormal heart rhythm and, as of 2020, affects more than 33 million people worldwide [26]. As of 2014, it affected about 2 to 3\% of the population of Europe and North America [27]. Due to AF, some patients need to constantly take blood thinners (platelet aggregation inhibitors and/or anticoagulants) to prevent blood clots, which can be very costly and can have very serious side effects, such as bleeding or hemorrhagic stroke.

The possible pharmacological strategies for AF treatment are the following:

- Development and improvement of existing antiarrhythmic agents: Amiodarone derivates, Multi-channel blockers, etc.

- $\quad$ Atrial selective therapeutic agents (ARDA): $\mathrm{I}_{\mathrm{Kur}}$ blocker; $\mathrm{I}_{\mathrm{K}, \mathrm{Ach}}$ blocker; $\mathrm{I}_{\mathrm{Na}}, \mathrm{I}_{\mathrm{Kr}}$ blockers

- Upstream therapy agents, drugs affecting structural remodeling; inflammation; hypertrophy; oxidative stress; etc.,

- Gap junction modulators: Antiarrhythmic peptides affecting connexins Cx40 and Cx43

The most promising strategy to treat $\mathrm{AF}$ that avoids ventricular proarrhythmic side effects is the development of drugs known as "atrial selective drugs". This concept would exploit distinct differences in expression patterns of individual ion channels and their different contribution to refractoriness between atrial and ventricular myocytes. Such atrial specific targets would be the following three known atrial specific ionic currents: (a) the ultra-rapid delayed rectified potassium current $\left(\mathrm{I}_{\mathrm{Kur}}\right)$; (b) the acetylcholine-sensitive inward rectifier potassium current $\left(\mathrm{I}_{\mathrm{K}, \mathrm{ACh}}\right)$; (c) the constitutively active $\mathrm{I}_{\mathrm{K}, \mathrm{ACh}}$ currents (i.e., which are active even in the absence of agonists at muscarinic receptors).

Inhibition of the ion flow through Kv1.5, i.e., blocking $\mathrm{I}_{\mathrm{Kur}}$, eliminates a component of the repolarizing current during atrial AP, thus prolonging the duration of the AP [12]. Almost all of the known Kv1.5 blockers are exclusively small molecules [8,28-30]. Pharmaceutical companies have made great efforts to develop selective $\mathrm{I}_{\mathrm{Kur}}$ blockers as new pharmacological agents against AF. As a result, many new $\mathrm{I}_{\text {Kur }}$ blockers have been developed and tested since the beginning of this century: AVE0118, XEN-D101, DPO-1, vernakalant, etc.

AVE0118 (Figure 2) is a biphenyl derivative developed by Sanofi-Aventis. AVE0118 blocks $\mathrm{I}_{\mathrm{Kur}}$ at micromolar concentrations in both native human atrial cells and Kv1.5 channel systems. In addition to the blocking of $\mathrm{I}_{\mathrm{Kur}}$, the drug also blocked $\mathrm{I}_{\mathrm{to}}$ and $\mathrm{I}_{\mathrm{K}, \mathrm{ACh}}$ currents at a similar concentration range [31,32]. 


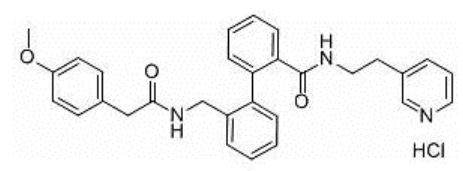

Figure 2. Structure of AVE0118.

AVE0118 shortened APD and ERP in atrial tissue from patients in sinus rhythm (SR), whereas APD/ERP was only slightly prolonged in tissues from patients in AF [32]. This observation is consistent with a previous study with the non-selective $\mathrm{I}_{\text {Kur }}$ blocker 4-aminopyridine [33]. AVE0118 has not been published in clinical trials and it appears that its development as a potential antirrhythmic drug is likely to have been halted. However, the compound was recently proposed as a new pharmacological tool for the treatment of obstructive sleep apnea [34].

XEN-D0101 (Figure 3) is an experimental compound developed by a small R\&D company (Xention Ltd., Cambridge, UK). A first clinical trial with XEN-D0103 did not reduce the burden of AF in patients with paroxysmal AF [35].<smiles>O=C(NCCO)C1CCCN(c2nc(NCc3ccccn3)c3c(-c4ccccc4)csc3n2)C1</smiles>

Figure 3. Structure of XEN-D0101.

DPO-1 (Diphenylphosphine oxide, Figure 4). DPO-1 blocks I Kur $_{\text {rate-dependently }}$ at nanomolar concentrations in isolated human atrial myocytes. DPO-1 blocks other currents (such as $\mathrm{I}_{\mathrm{to}}$ ) at higher micromolar concentrations. Furthermore, DPO-1 induced prolongation of APD in AF plateau, elevation and shortening in SR only in human atrial tissue and not in the ventricle [36].<smiles>CC1CCC(C(C)C)C(P(=O)(c2ccccc2)c2ccccc2)C1</smiles>

Figure 4. Structure of DPO-1.

Vernakalant (RSD1235, Cardiome and Astellas, Figure 5) is the molecule in the most advanced phase of study. It was approved by the European authorities, but the FDA did not allow intravenous conversion of AF. Vernakalant inhibited $\mathrm{I}_{\text {Kur }}$ in a positive frequencydependent manner [37,38]. However, in human atrial cardiomyocytes, its effects on $\mathrm{I}_{\text {to1 }}$ are small. In human atrial preparations vernakalant suppresses upstroke velocity, suggesting relevant inhibition of $\mathrm{I}_{\mathrm{Na}}[37,38]$, so it can be considered a multichannel inhibitor rather than a selective $\mathrm{I}_{\text {Kur }}$ blocker. Vernakalant has rapid offset kinetics at sodium channels, so it was not expected to cause proarrhythmia and conduction disturbances at low heart rates $[39,40]$. However, vernakalant slowed conduction velocity at physiological heart rate both in the atria and in the ventricles of human hearts, calling into question the atrial selectivity of the drug effect [41]. Numerous clinical studies have shown the safety and efficacy of vernakalant in the transformation of AF. The AVRO study (phase III clinical study) demonstrated that vernakalant has superior efficacy compared with amiodarone in the acute conversion of recent cardiac arrhythmias AF [42,43]. In another study, vernakalant was shown to be safe and effective in combination with electrical cardioversion [44] and was approved for clinical practice in the European Union in 2010 (but not in the US [45]). 


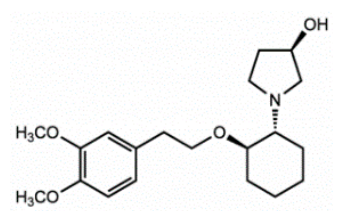

Figure 5. Stucture of Vernakalant.

\section{Peptide Modulators of the Kv Channels}

Animal venoms are a complex cocktail of oligopeptides, free amino acids, nucleotides, low molecular weight salts, organic compounds, peptides and proteins [46]. These venoms are employed for prey hunting and protection against predators [47]. In this complex mixture of bioactive molecules, the lethal toxin often represents only a minor proportion, along which many other non-lethal components with interesting bioactivities are present, which can be used for the development of pharmaceutical agents, insecticides and research tools in the characterization of ion channels [48].

Research on peptide modulators of $\mathrm{Kv}$ channels started in the 1980s [30]. To date, $\sim 460$ toxins have been reported exclusively for voltage-gated $\mathrm{K}^{+}$channels (Figure 6), scorpion venoms being the major source of these molecules with 203 entries, followed by the spider venoms with 102 [49-51]. These arachnid venom-derived peptides interact with $\mathrm{Kv}$ channels in two different modes: either as pore blockers or as gating modifiers, with a very specific interaction with different regions of the ion channels.

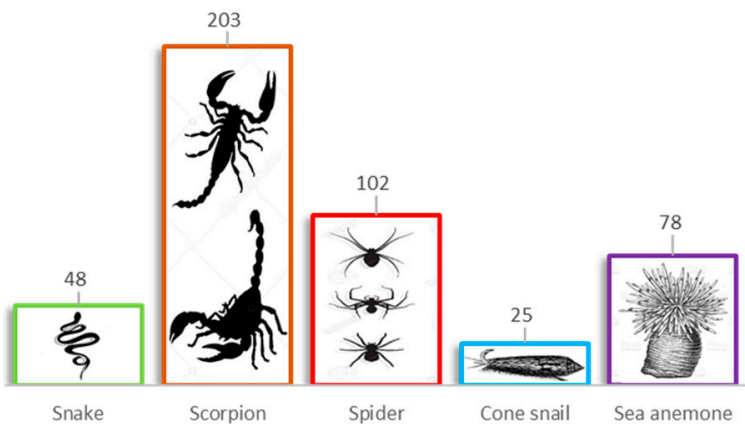

Figure 6. Peptide modulators of the voltage-gated potassium $(\mathrm{Kv})$ channels. Numbers above the boxes indicate the number of toxins isolated to target $\mathrm{Kv}$ channels.

\subsection{Pore Blocker Peptides}

All known scorpion toxins affecting potassium channels (KTx) physically occlude the channel pore, which makes them pore blockers [52]. Based on homology, cysteine pairing pattern and activity, KTxs have been classified into six families: $\alpha-\mathrm{KTx}, \beta-\mathrm{KTx}, \gamma-\mathrm{KTx}$, K-KTx, $\delta$-KTx [53] and $\varepsilon$-KTx (Figure 7).

The $\alpha$-KTx family is the largest family, with 174 members grouped in 31 subfamilies, followed by the $\beta$-KTx family with 35 members grouped in 3 subfamilies and the $\gamma$-KTx family with 30 members grouped in 5 subfamilies [51,54-56]. All these three families share a common structural motif comprising one or two $\alpha$-helices connected to a triple-stranded antiparallel $\beta$-sheet stabilized by three or four disulfide bonds $(\mathrm{CS} \alpha / \beta)$ [55]. The majority of the members of the $\alpha-\mathrm{KTx}$ family have been isolated from the venoms of scorpions of the Buthidae family [57]. These peptides range from 23 to 43 residues in size and recognize Shaker-type $\mathrm{Kv}$ channels and $\mathrm{Ca}^{2+}$-activated $\mathrm{K}^{+}$channels [58]. $\beta$-KTx peptides are longer than the $\alpha-\mathrm{KTx}$, ranging from 45 to 75 residues in size. The difference between the sizes of these families can be explained by an $\mathrm{N}$-terminus $\alpha$-helix with cytolytic and/or antimicrobial activity, followed by the C-terminal region with a $\mathrm{CS} \alpha / \beta$ motif that confers the $\mathrm{K}^{+}$channels blocking activity [59]. Peptides of the $\gamma-\mathrm{KT} x$ family were discovered in the venom of scorpions of the genus Centruroides, Mesobuthus and Buthus [60]. Their length ranges from 36 to 47 residues, and they are described as mainly targeting $\mathrm{K}^{+}$channels of the ERG (ether-á-go-go gene) family [61]. 


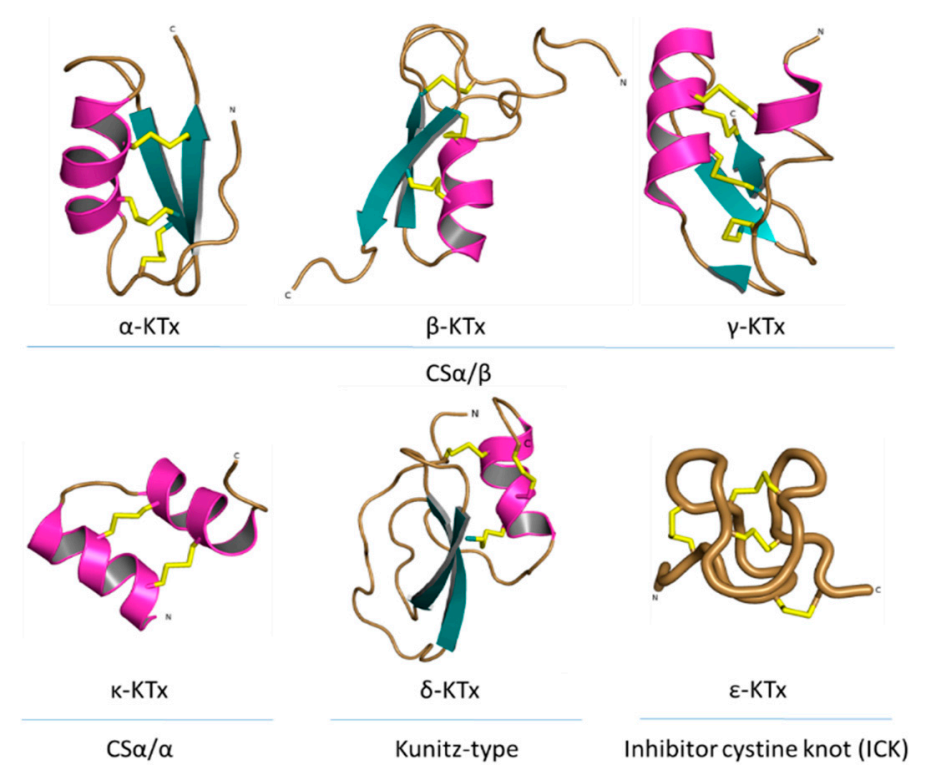

Figure 7. Structural folds present in the KTx families. $\alpha$-KTx: MgTx (1MTX), $\beta$-KTx: HgeScplp1

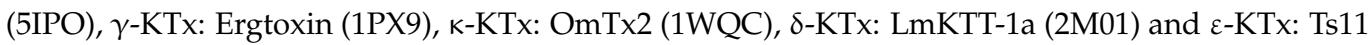
(2MSF). PDB entries are shown in parentheses.

The k-KTx family is comprised of 18 members grouped in 5 subfamilies. All these peptides have been isolated from scorpion venoms of the genus Heterometrus and Opisthacanthus. Peptides of this family consist of 22 to 28 amino acid residues and are considered weak inhibitors of $\mathrm{K}^{+}$channels (all of them showing effect in the $\mu \mathrm{M}$ range). The structure of $\mathrm{k}-\mathrm{KTx}$ peptides is characterized by two parallel $\alpha$-helices linked by two disulfide bridges $(\mathrm{CS} \alpha / \alpha)$ [62].

The $\delta$-KTx family is comprised of 7 members grouped in 3 subfamilies, ranging from 59 to 70 residues, which have been isolated from the venom of scorpions of the genus Hadrurus, Mesobuthus and Lychas. The members of the $\delta$-KTx family are characterized by a Kunitz-type fold, which is represented by two antiparallel $\beta$-strands and two, or more often, one helical region [63]. Moreover, $\delta$-KTx members possess a dual activity inhibiting proteolytic enzymes (e.g., trypsin) in nanomolar concentration and blocking $\mathrm{Kv}$ channels [64].

The $\varepsilon$-KTx family is the smallest one. It is comprised of only two members (29 amino acid residues length), both of them isolated from the venom of the scorpion Tityus serrulatus. The structure of these peptides consists of an inhibitor cystine knot type scaffold (ICK). However, the structure is completely devoid of the classical secondary structure elements ( $\alpha$-helix and/or $\beta$-strand) [65].

In previous works, a seventh family of KTx is mentioned [57,66]. This family, known as $\lambda$-KTx, also presents an ICK scaffold, but unlike the $\varepsilon$-KTx family, the structure is a CS $\alpha / \beta$ fold. The best-characterized peptide of this family, the $\lambda$-MeuTx-1, showed a blocking effect in the Shaker $\mathrm{K}^{+}$channel but not in other $\mathrm{Kv}$ channels [67]. However, nowadays, this peptide has been reclassified into the scorpion calcin-like family, which is why the $\lambda$-KTx family does not appear in the classification of the KTx anymore.

\section{Mechanism of Action of the Pore Blockers}

KTxs can interact with $\mathrm{Kv}$ channels through different mechanisms. However, three major mechanisms have been described. The first one is the so-called "functional dyad" model, which is the most frequently identified and the best characterized. The dyad is composed of two highly conserved amino acid residues. In the first position, there is a lysine and in the second position, a neighboring aromatic or aliphatic residue [18]. In this model, the $\beta$-sheet side of the toxin faces the entrance of the channel pore and the lysine side chain in the selectivity filter (Figure 8). The hydrophobic interaction of the second 
amino acid is involved mostly in the high-affinity binding [58]. The lysine side chain is attracted to the pore, where a ring of aspartate or glutamate residues surrounds it [68], while the aromatic or aliphatic residue might interact with a tyrosine or tryptophan residue of one of the channel $\alpha$-subunits [69]. The second mechanism is called the "ring of basic residues". This mechanism has been demonstrated for the entire $\alpha$-KTx subfamily 5 and $\alpha-K T x 4.2$ interacting with the KCa2.x channels. In this model, a cluster of basic residues (2-4 Arg and Lys) interacts with residues of the channel situated at the turret and the bottom of the vestibule. However, this cluster is located in the $\alpha$-helix of the toxin instead of the $\beta$-hairpin $[69,70]$. The last model involved the interaction of the $\gamma$-KTxs with the ERG channels. The binding occurs in a hydrophobic binding site comprising an amphipathic $\alpha$-helix located in the S5-P linker and the P-S6 linker. In this interaction, the toxins bind in an off-center position in the outer vestibule; however, the lack of the Lys residue found in the functional dyad lead to a reduction but not a total occlusion of $\mathrm{K}^{+}$current [71].

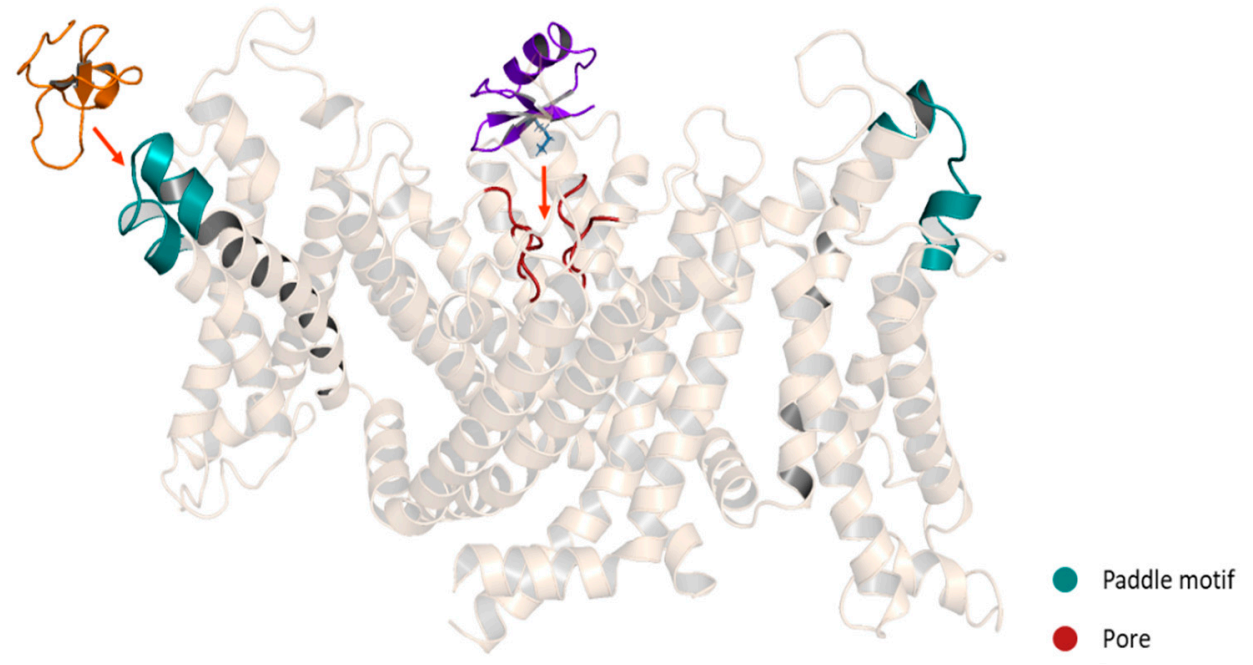

Figure 8. Schematic representation of $\mathrm{Kv}$ modulators binding sites. Purple: ChTx, pore blocker. Orange: HaTx1, gating modifier. A chimeric structure of the channels Kv1.2-2.1 is shown (5WIE). Helices in front and behind the structure were removed for a better appreciation.

\subsection{Gating Modifiers Peptides}

In contrast to scorpion venom peptides, spider venom peptides are mostly gating modifiers. These peptides range from 29 to 35 residues and were isolated mainly from the venoms of the Theraphosidae family. They are characterized by a promiscuous selectivity between $\mathrm{Ca}^{2+}, \mathrm{Na}^{+}$and $\mathrm{K}^{+}$channels. For example, the Hanatoxin (HaTx1) [72] and HpTx1 [73] (patent) toxins show effect on $\mathrm{Ca}^{2+}$ and $\mathrm{K}^{+}$channels. On the other hand, the VsTx1 [74], PaTx1 [75,76], HmTx1 [77,78] and GiTx1 [79] toxins have been reported as $\mathrm{Na}^{+}$ and $\mathrm{K}^{+}$channel modulators. Furthermore, it has been discovered that in the toxin-channel interaction, the lipids in the cell membrane are also involved [80,81]. For $\mathrm{Kv}$ channels, the selectivity of these toxins becomes a little tighter since all of these peptides affect mainly $\mathrm{Kv} 2$ and/or Kv4 subfamilies [66]. Although, peptides as the GiTx1 [79] and JZTX-1 [82] have shown an effect on hERG channels.

Spider gating modifier peptides present an ICK scaffold, where the $\beta$-sheet typically comprises two $\beta$ strands (a third strand in the $\mathrm{N}$-terminal can be present sometimes) stabilized by a cysteine knot. This knot comprises a ring formed by two disulfides and the intervening polypeptide backbone, with a third disulfide bridge going through the ring to create a pseudo-knot (Figure 9) [83]. The ICK turns these peptides into hyperstable proteins with tremendous chemical, thermal and biological stability [84]. 


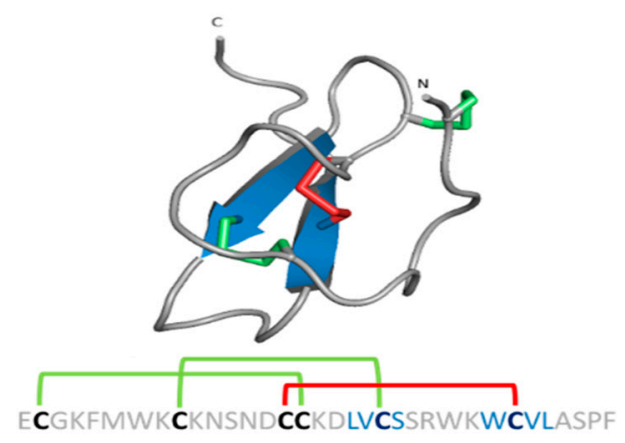

Figure 9. ICK scaffold in peptide gating modifiers. Sequence and structure of the VsTx1 toxin. Disulfide bridge ring is shown in green.

\section{Mechanism of Action of the Gating Modifiers}

Spider gating modifier peptides bind to a region of the channel that changes conformation during gating and influences the gating mechanism by altering the relative stability of closed, open or inactivated states [85]. Most of the peptides possess a cluster of solvent-exposed hydrophobic residues (hydrophobic patch) surrounded by highly polar residues (charge belt), enhancing the affinity for the $\mathrm{Kv}$ channels by allowing the toxins to partition into the membrane [86]. These peptides interact with the $\mathrm{Kv}$ channel in the VSD region, specifically with the paddle motif, a mobile helix-turn-helix motif composed of the C-terminal portion of S3, and the S4 helix (Figure 8). The specific interactions have been revealed for several toxins. For example, in the binding between the HaTx1 and the Kv2.1 channel, the interaction with the F274 and E277 in the C-terminal portion of S3 plays a crucial role [87]. These molecular determinants are shared for the JZTX-XI toxin and the Kv2.1 channel interaction [88] and possibly for the interaction between the JZTX toxins and the hERG channels since the binding sites in the paddle motif of Kv2.1 (I273, F274 and E277) are conserved in the paddle motif of the hERG channel (I512, F513 and E518) [82]. On the other hand, despite HpTx2 binding to the same paddle motif in the $\mathrm{Kv} 4$ channel, HpTx2 binding does not require a charged amino acid for the interaction since hydrophobic residues (L275 and V276) are the most important for the binding [89]. Moreover, in experiments using chimera constructs in which the linker region S3-S4 of the Kv2.1 channel (TLTx1-insensitive) was replaced by the corresponding Kv4.2 domain, it was observed that the Kv2.1 channel became sensitive to TLTx1 [90]. These data suggest that even if toxins share the same binding site (paddle motif), the molecular determinants for the interaction can change between different families of $\mathrm{Kv}$ channels.

\section{Osu1 and Ts6: The Known Peptide Modulators of the Kv1.5}

To the best of our knowledge, only two peptides are known in the literature that have modulated the Kv1.5 ion current: Osu1 [91] and Ts6 [92,93]. Osu1 is a peptide isolated from the venom of a tarantula, called Oculicosa supermirabilis. It is a 64 amino acid peptide with a mass of $7478 \mathrm{Da}$, and its spatial structure is formed by four disulfide bridges (Figure 10) [91]. Electrophysiological recordings showed that the total venom of Oculicosa supermirabilis, as well as the native and recombinant Osu1, slowed the activation kinetics of the Kv1.5 current at $\sim \mu \mathrm{M}$ peptide concentration. The slowing of the activation kinetics of the current was consistent with a $\sim 40 \mathrm{mV}$ shift in the conductance vs. membrane potential (G-V) relationship of the Osu1 bound channels, as compared to the toxin-free clontrol. In other words, the membrane potential at which $50 \%$ of the Kv1.5 channels are open $\left(\mathrm{V}_{1 / 2}\right)$ is about $40 \mathrm{mV}$ more positive when Osu1 is present. This rightward shift in the G-V indicates that Osu1 is most likely not bound to the pore of Kv1.5 but rather to the VSD, hindering its movement at depolarization; thus, $\mathrm{Kv} 1.5$ opens only at more positive voltages. As a result, in a certain membrane potential range, especially at mild depolarizations close to the activation threshold of the channel, the binding of Osu1 to the voltage sensor appears as an 
inhibitory effect. Based on this, it is possible to reduce the $\mathrm{I}_{\text {Kur }}$ current through Kv1.5 using Osu1 and thereby influence the shape and duration of the AP in the atrium of the heart.

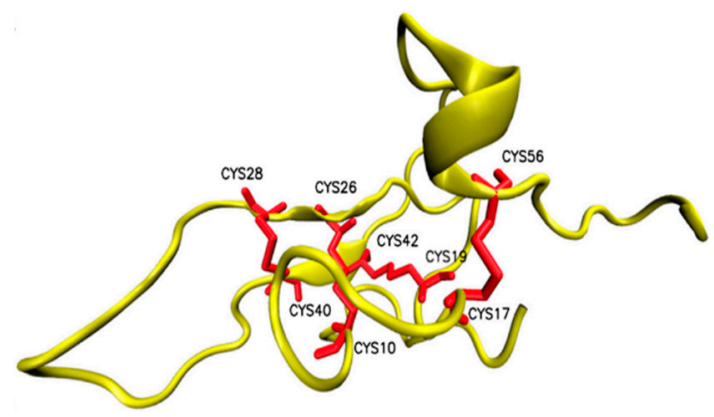

Figure 10. Structure of Osu1 peptide based on homology model.

Ts6 ( $\alpha$-KTx 12.1), previously known as butantoxin, also known as TsTX-IV, is the other known Kv1.5 modulating peptide. This peptide was isolated from the venom of the scorpion Tityus serrulatus. It consists of 40 amino acids with a molecular mass of $4506 \mathrm{Da}$ and with 8 cysteine residues (Figure 11) [92-94]. Ts6 is primarily known as a peptide that inhibits Kv1.2 and Kv1.3 ion channels at nM concentrations (the $\mathrm{IC}_{50}$ values were $6.19 \pm 0.35 \mathrm{nM}$ for Kv1.2 and $0.55 \pm 0.20 \mathrm{nM}$ for Kv1.3) [92], but in the selectivity experiments, Ts6 also inhibited the current flowing through $\mathrm{Kv} 1.5$ at $\mu \mathrm{M}$ concentrations. Besides its effects on ion channels, Ts6 has also shown a pro-inflammatory effect by increasing the levels of cytokines, such as interleukin-6 (IL-6), both in in vivo and in vitro models [94,95]. IL-6 increase can cause cardiac or systemic inflammation, which in turn can rapidly lead to atrial electrical remodeling [96]. Thus, any other potential Kv1.5 blocking peptides should be tested for such adverse effects. After this report on the blocking effect of Ts6, no more results have been published in the literature that further investigated the inhibition of Kv1.5 by Ts6 or that any attempt had been made to utilize this knowledge in any way, such as in the treatment of atrial fibrillation.

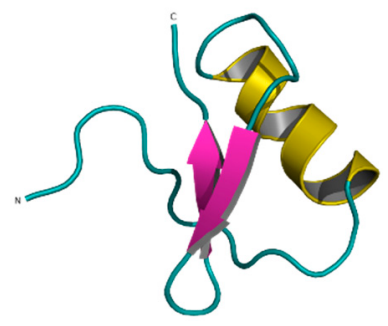

Figure 11. Ts6 toxin (1C56).

\section{Selectivity of Kv1.5 Inhibitors}

Selectivity plays an important role in the potential therapeutic application of an ion channel blocker since the higher the selectivity, the lower the risk of side effects. As mentioned earlier, several small molecules targeting the Kv1.5 channel have been tested as candidates for the treatment of AF. In all of them, affinity and selectivity vary over a broad spectrum. AVE0118 exhibits an $\mathrm{IC}_{50}$ of $6.9 \mu \mathrm{M}$ for the Kv1.5. However, in the same concentration range $(10 \mu \mathrm{M}), \mathrm{AVE} 0118$ is able to block $\mathrm{I}_{\text {to }}$ and $\mathrm{I}_{\mathrm{K}, \mathrm{ACh}}$ [32]. The same is true for vernakalant, which is a multichannel blocker in the $\mu \mathrm{M}$ range [38]. XEN-D0103 inhibits Kv1.5 with an $\mathrm{IC}_{50}$ of $25 \mathrm{nM}$ and shows more than 500-fold selectivity over hERG, Kv4.3, Nav1.5, Cav1.2 and Kir2.1 [97]. Similarly, DPO-1 shows a Kd value of $30 \mathrm{nM}$ and blocks other channels only in the $\mu \mathrm{M}$ range [36].

Peptides in general have a much larger interacting surface with ion channels compared to small molecule inhibitors. Therefore, due to multiple points of contact, peptides potentially exhibit higher affinity and selectivity for channels with a lower chance of inhibition or modification of other ion channels than known small molecule inhibitors. For example, 
the peptide toxin $\operatorname{Vm} 24(\alpha-\mathrm{KTx} 23.1)$ shows high affinity $(\mathrm{Kd}=2.9 \mathrm{pM})$ for the $\mathrm{Kv} 1.3$ channel and exhibits more than 1500-fold selectivity over other ion channels, including other Kv channels, KCa channels and Nav1.5 [98]. On the other hand, the small molecule tetraethylammonium (TEA) blocks numerous types of $\mathrm{Kv}$ channels, including members of the Kv1, Kv2 and Kv3 families, as well as KCa channels with a Kd value between $0.4 \mathrm{mM}$ and $8 \mathrm{mM}$ [99]. Pap-1 is a small molecule with one of the highest affinities for $\mathrm{Kv}$ channels: it blocks Kv1.3 in $\mathrm{nM}$ concentration $\left(\mathrm{EC}_{50}=2 \mathrm{nM}\right)$. PAP-1 is 23-fold selective over Kv1.5, 33- to 125-fold selective over other Kv1-family channels and 500- to 7500-fold selective over other $\mathrm{K}^{+}, \mathrm{Na}^{+}, \mathrm{Ca}^{2+}$ and $\mathrm{Cl}^{-}$channels [100]. However, this $\mathrm{nM}$ affinity is still 1000 times lower compared to the $\mathrm{pM}$ affinity of the peptide Vm24. Another example is the toxin Gr1b. This peptide inhibits the Nav1.7 channel with a Kd value of $40 \mathrm{nM}$ and exhibits 10- to 30-fold selectivity over other Nav channels [74]. In this case, the small molecule tetrodotoxin (TTX) shows a slightly higher affinity for Nav channels (Kd value of 4 to $25 \mathrm{nM}$ ). However, TTX can block different subtypes of Nav channels with almost the same $\mathrm{Kd}$, showing a selectivity between 1.5- to 6-fold [101]. GX-674 small molecule inhibits Nav1.7 at subnanomolar concentration $(\mathrm{Kd}=0.1 \mathrm{nM})$, but it is not selective over Nav1.6 and Nav1.2 [102].

So far, only Osu1 and Ts6 have been reported as Kv1.5 peptide inhibitors. Native Osu1 (peptide purified directly from venom) showed inhibitory activity at $0.9 \mu \mathrm{M}$, while recombinant Osu1 (expressed in bacteria) showed the same activity at $3 \mu \mathrm{M}$ [91]. Nothing is yet known about the selectivity of Osu1. Ts6 inhibited Kv1.5 at a concentration of $1 \mu \mathrm{M}$. However, Ts6 also inhibited Kv1.2, Kv1.3 and Shaker channels with higher affinity (in nM) and Kv1.6, Kv7.2, Kv7.4 and hERG with similar affinity as Kv1.5 (in $\mu$ M) [92]. One of the main reasons for the lack of peptide inhibitors for Kv1.5 is the presence of a positively charged Arg residue (R487) in the pore region of the channel, a feature missing in other Kv channels [103,104], which prevents $\mathrm{Kv}$ channel pore blocker peptides from binding to Kv1.5. The mutation of this Arg to Val (R487V) or Tyr (R487Y) made Kv1.5 sensitive to BgK, a known inhibitor toxin for Kv1 channels from the sea anemone Bunodosoma granulifera $[103,105,106]$. Knowing the binding mechanism of other toxins to $\mathrm{Kv}$ channels and the particular properties of the Kv1.5 channel, the selectivity of Ts6 and Osu1 (and other peptides) and their affinity for Kv1.5 could be improved by rational drug design in which their amino acid sequences are modified in a targeted way guided by in silico docking experiments.

\section{Improving Selectivity and Affinity of Peptide Toxins}

To improve the selectivity and the affinity of peptide toxins, it is necessary to understand well the properties of peptides isolated from animal venoms; however, some barriers must be overcome. Most of the time, it is difficult to isolate or study a peptide from the extremely limited amount of venom that can be obtained from the animals. This problem can be solved by chemical synthesis or recombinant expression of these peptides. After appropriate standardization of the expression protocols, a sufficient amount of peptide can be obtained [105-107] to fully characterize the biological activity of the peptides. However, as mentioned earlier, most toxin peptides are rich in disulfide bonds, resulting in low yields of the bioactive product with the desired disulfide bridge configuration.

\subsection{Achieving the Native Peptide Scaffold}

The primary, secondary and tertiary structure of the peptides are crucial to their specificity and functionality. Generally, methods to elucidate the peptide structure, such as NMR and X-ray studies, require an amount of toxin that is difficult to obtain from the natural source. Recombinant expression and chemical synthesis of peptides are excellent tools to reach the required amounts of the toxin. There are different recombinant expression systems to produce the target peptide. To date, Escherichia coli $(E$. coli) represents the most widely used heterologous expression system in which recombinant peptides are usually accumulated in the cytoplasm. However, because of the disulfide bonds, they tend to 
be misfolded and aggregate [108]. To solve this problem, some alternatives have been developed: (1) several E. coli strains have been genetically modified to generate strains in which the reducing cytoplasmic environment is more favorable for disulfide bond formation $[109,110],(2)$ use of vectors with a signal sequence to take the protein into the periplasmic space with a more oxidizing environment and proteins that catalyze and rearrange the disulfide bonds [111], and (3) co-expression of the peptide along with fusion proteins or chaperones that enhance proper folding [112]. If the E. coli system does not work, yeast is the next option. These cells are used to produce recombinant proteins that are not produced well in E. coli because of folding issues or the need for glycosylation. Yeasts are easier and cheaper to work with than insect or mammalian cells and are easily adapted to fermentation processes. The two most commonly used yeast strains are S. cerevisiae and P. pastoris $[107,113]$. Although E. coli and yeast are the most commonly used expression systems for animal toxin production, other systems such as insect cells have also been reported [114,115].

On the other hand, there is solid-phase peptide synthesis (SPPS), which is an efficient method for producing peptides and small proteins. Some important advantages are that this approach allows the incorporation of non-native elements, such as $\mathrm{N}$-substituted and D-amino acids, and the replacement of the backbone amide bonds. SPPS can also be used to generate peptides that cannot be produced by expression systems because they are toxic [116]. A disadvantage of SPPS over recombinant expression of toxins is that SPPS requires extensive screening of in vitro folding conditions, which can be further complicated because many toxins have multiple disulfide bonds [117]. However, it is worth noting that if the native disulfide pattern of the peptide is known, Cys with protecting groups can be used. These Cys protecting groups can be selectively removed to create a bond between two specific Cys in the structure, resulting in a peptide with the same Cys framework as the native peptide [118].

\subsection{Uncovering Amino Acids Involved in Selectivity and Affinity}

Once the peptide (recombinant or synthetic) has been produced with structural and biological properties similar to the native one, selectivity and affinity enhancement can be performed. The first step would be to know the amino acids involved in the interaction of the peptide with the channel. Solving the structure of the peptide-channel complex would reveal the amino acids that bind directly to the channel. Banerjee et al. [68] have used X-ray crystallography to study the structure of the complex formed by charybdotoxin (ChTx) ( $\alpha$-KTx 1.1) and a chimeric version of a voltage-gated potassium channel formed by Kv2.1 and Kv1.2. They confirmed the occlusion of the channel pore by Lys27 and showed the interactions between the amino acids of the toxin and the amino acids located in the mouth of the channel pore. Similarl to X-ray crystallography, cryo-electro microscopy was used to investigate ion channel-peptide toxin complex with Nav1.7 and ProTx2 [119,120]. Although these approaches can provide accurate information, obtaining the crystal could be difficult. For this reason, basic alanine scanning has become a widely used strategy for identifying side chains that play a key role in toxin-channel interactions. By mutating each native amino acid in the primary sequence to alanine one at a time, the importance of each amino acid in the binding interaction can be revealed [121]. Then, the amino acids directly involved in the binding interaction can be further optimized to improve the overall potency and selectivity of the peptides [122]. Double-mutant cycle analysis is another method to measure the strength of intermolecular pairwise interactions in protein-ligand and proteinprotein complexes [123]. However, these techniques are time-consuming processes that become less practical with increasing size of the peptides under investigation. Therefore, computational methods are valuable tools to construct accurate models of toxin-channel complexes. Docking methods and molecular dynamics simulations can be used to find valuable hints to identify amino acid residues that need to be mutated to achieve the desired selectivity and then calculate the free energy perturbation between the native toxin and its analogs to evaluate the effects on binding of each mutant [124]. In these docking 
approaches, multiple related peptides can be tested in one specific channel to determine how structure and small changes in amino acid sequence affect the binding interaction. Docking analysis of charybdotoxin (ChTx) and margatoxin (MgTx) in the native version and the mutant version of Kv1.3 revealed not only the difference between the interaction of the two toxins but also how the toxins were reoriented to block the mutant channel, which helped to explain the results observed in patch-clamp [125]. On the other hand, it is possible to use docking to analyze the selectivity of one toxin for multiple channels. In this way, it was explained why the toxin Css20 ( $\alpha$-KTx 2.13) is more selective for channels Kv1.2 and Kv1.3 than for Kv1.1 and Kv1.4 [126].

With these methodologies, the rational design of more potent and selective peptides can be done. For example, MeKTx13-3 ( $\alpha$-KTx 3.19) is a toxin with a promiscuous effect on $\mathrm{Kv1} 1$, Kv1.2, Kv1.3 and Kv1.6 channels, but the mutation or addition of specific residues improved either selectivity against Kv1.3 [127] or affinity for the Kv1.1 channel [128]. Similarly, the [N17A/F32T]-AnTx (an analog of AnTx, $\alpha$-KTx 6.12) showed a 16,000-fold increase in selectivity towards the Kv1.3 channel while maintaining the high affinity of the native peptide for the channel [129]. Another approach to find amino acids that can be used as targets for improving selectivity and affinity is to analyze the sequence of related toxins. For example, the toxin OdK1 ( $\alpha$-KTx 8.5) differs from OSK3 ( $\alpha$-KTx 8.8) only by two C-terminal residues but shows a pronounced preference for Kv1.2, implying that these two amino acid residues are involved in the selectivity for the channel [130]. However, it is not only amino acid changes that can affect toxin activity. It has been shown that amidation in the C-terminus of urotoxin $(\alpha-K T x$ 3.19) increases its potency towards the Kv1.2 channel [131]. Moreover, several scorpion toxins have been shown to require C-terminus amidation for full biological activity, without which potency is severely reduced [132].

The above techniques attempt to improve the affinity and selectivity of peptides by specific changes in the amino acid sequence. However, peptides with blocking activity resulting from random recombination of related protein regions have also been reported. This recombination creates libraries of more than 1,000,000 different peptides that are tested by phage display to select chimeras that show interaction with the desired channels [133]. Similarly, fragment-based drug discovery is an excellent technique for discovering drugs. This approach first identifies starting points as small molecules. Then, these fragments are expanded or linked together to generate drugs. Although fragments bind to proteins with relatively low affinity, they form high quality binding interactions with the protein as they overcome a significant entropy barrier to bind [134,135].

In addition, there are other methods and techniques for increasing the affinity and selectivity of a peptide. For example: acidic-residue-function-guided drug design; chemical modification; residue truncation; binding interface modulation; reducing conformational flexibility; scaffold-/target-biased strategies; Artificial Intelligence-guided drug design [136-138].The overall methodological background and information on the interaction between toxins and $\mathrm{Kv}$ channels allows us to work with toxins, such as Osu1 and Ts6, generating and testing analogs until the toxin with the best affinity and selectivity is found, or to find analogs of other toxins related to Osu1 or Ts6 that may have similar activity on the Kv1.5 channel.

\section{Testing Kv1.5 Modulation in AF Models}

Different AF models exist to investigate the characteristics and parameters of AF and to test potential drug candidates. One of these is the various cell lines that have been created specifically for this purpose. An atrial muscle cell-derived cell line (iAM, immortalized atrial myocyte) has been developed from rat cells [139]. In their work, the authors performed RT-qPCR analysis of iAMs in different stages of differentiation and showed a rapid increase in mRNA levels of cardiac transcription factors, ion channels, $\mathrm{Ca}^{2+}$ handling proteins and sarcomeric proteins. iAMs acquired properties of atrial rather than ventricular myocytes, and a monolayer cell culture created from the iAM was developed as 
an in vitro model of AF. In this model, a spiral wave can be generated that returns to and maintains itself as re-entrant circuit, using optical voltage mapping and high-frequency $(10-50 \mathrm{~Hz})$ electrical point stimulation. The resulting re-entrant circuits could be terminated by prolonging the APD of the iAMs using a known $\mathrm{K}^{+}$channel inhibitor, tertiapin (a peptide isolated from honeybee venom, Kir3.x-specific inhibitor). Based on these results, this AF model system seems to be suitable to test other $\mathrm{K}^{+}$channel inhibitors and modulators.

However, before testing a drug candidate molecule in this AF model, it is useful to test it on individual cells of cell lines focusing on the action potential parameters, such as AP duration $\left(\mathrm{APD}_{90}\right), \mathrm{AP}$ amplitude, the maximum speed of depolarization $\left(\mathrm{V}_{\max }\right)$ and plateau potential at the point corresponding to $50 \%$ duration of $\mathrm{APD}_{90}$ (plateau50). If these listed parameters are not affected by the molecule to be tested, it is not expected to affect the AF model either. The most important parameter is $\mathrm{APD}_{90}$ : if prolonged, there is a good chance that fibrillation will stop in the AF model. The same group is currently working on creating a human version of the iAM cell line (hiAM) [140].

A similar cell line AF model was developed by Peter H. Backx's group. They used human embryonic stem cells (hESCs) to generate atrial-like cardiomyocytes (CMs) and to create an AF model for pharmacological testing. Using optical mapping techniques, atrial-like confluent CM cells showed uniform AP propagation and rapid re-entrant rotor patterns. They tested anti-arrhythmic drugs (flecainide, dofetilide in $\mu \mathrm{M}$ concentration) on single cells and cell sheets. Flecainide profoundly slowed upstroke velocity without affecting AP duration, while dofetilide prolonged APs and reduced cycle lengths of rotors in cell sheets [141].

LOF mutations in the PITX2 (specifically expressed in the left human atrium) transcription factor gene have been shown to cause familial AF. Boris Greber's group generated a PITX2-deficient cell line to model AF and unravel PITX2-regulated downstream genes for drug target discovery. Their F1 cells were capable of spontaneously differentiating into cardiomyocytes; moreover, all cell lines could selectively be differentiated in a cardiac subtype-specific manner, i.e., form atrial or ventricular cardiomyocytes.

On the other hand, the anatomical and physiological similarities between humans and animals, particularly mammals, allow researchers to study a variety of mechanisms and novel therapies in animal models [142]. Despite AF being quite common in humans, spontaneously occurring AF has only been reported in relatively few animal species, such as cats, dogs, pigs, goats, sheep, cattle, horses, camelids and monkeys. In horses and cattle, the prevalence of spontaneous AF is the highest (about 2.5\%), whereas in the other animals spontaneous AF cases rarely occur as an isolated problem without other cardiac diseases [143]. For this reason, AF has to be induced in the animal model through raterelated electrical remodeling or with atrial-structural remodeling [144] using models such as rapid atrial tachypacing, heart failure-associated AF and vagal tone-induced AF [143]. In the following section, we will focus on experiments in which the effects of drugs targeting $\mathrm{I}_{\text {Kur }}$ have been studied in animal models. However, we refer readers to two reviews by Shuttler et al. (2020) [145] and Saljic et al. (2021) [143], where they discussed extensively the animals models for AF studies.

Efforts by pharmaceutical companies to find new selective $\mathrm{I}_{\mathrm{Kur}}$ blockers as novel pharmacological agents against AF have generated new data on the effects of these compounds in animal models. Some of these drugs are AVE0118, XEND101, DPO-1 and vernakalant [146], mentioned above. AVE0118 was tested in dogs and goats, showing fully restored atrial contraction without proarrhythmic effects on the ventricle $[147,148]$. Moreover, AVE0118 in combination with dofetilide or ibutilide showed effective cardioversion in persistent AF [149]. AVE1231 showed similar results in pigs and goats, prolonging atrial refractoriness with no effects on ECG intervals and ventricular repolarization [150]. In another study in dogs, XEN-D0101 and XEN-D0103 selectively blocked I Kur current and prolonged the atria effective refractory period and decreased the duration of AF [151,152]. The same results were observed when the compound DPO-1 was tested in dogs [153]. Vernakalant (RSD1235) has been approved in European countries for acute cardioversion 
of AF with recent onset. It has been tested in several animal models, including goats [154], pigs [155] and dogs [156]. However, nowadays, it is considered as a multichannel blocker rather than an $\mathrm{I}_{\text {Kur }}$ specific blocker [143].

Although none of the above cases involved experiments with peptides, it is clear that the use of cell lines and animal models for AF is a potential method for testing peptide inhibitors to discover and develop new drugs for the treatment and prevention of AF.

\section{Concluding Remarks}

The technology to make peptides more selective for a given ion channel is known, along with the computer modelling to aid design, and there are excellent tools to test the efficacy of the peptides. The selectivity of ion channel inhibitors is extremely important for future therapeutic application in order to reduce the unwanted side effects-the higher the selectivity, the lower the risk of side effects. In the literature, there are only two peptides, Osu1 and Ts6, which can bind to the Kv1.5 channel. They are the candidates to elucidate the mechanisms of interaction between peptides and the Kv1.5 channel. Improving their selectivity for $\mathrm{I}_{\mathrm{Kur}}$ can serve as an option for the treatment of atrial fibrillation.

Author Contributions: J.B., A.F., N.J., Z.V., G.P. and F.P.: writing—review and editing. All authors have read and agreed to the published version of the manuscript.

Funding: This work was supported by OTKA Bridging Fund 1G3DBKB0BFPF247 (FP), by János Bolyai Research Scholarship of the Hungarian Academy of Sciences (BO/00355/21/8) (FP), by the ÚNKP-21-5 New National Excellence Program of the Ministry for Innovation and Technology from the Source of the National Research, Development and Innovation Fund (FP), by OTKA/NKFIH K132906 (ZV) and K119417 (GP). The work/publication is supported by the EFOP-3.6.1-16-2016-00022 project. The project is co-financed by the European Union and the European Social Fund (JB and GP).

Institutional Review Board Statement: Not applicable.

Informed Consent Statement: Not applicable.

Data Availability Statement: Data sharing not applicable.

Conflicts of Interest: The authors declare no conflict of interest.

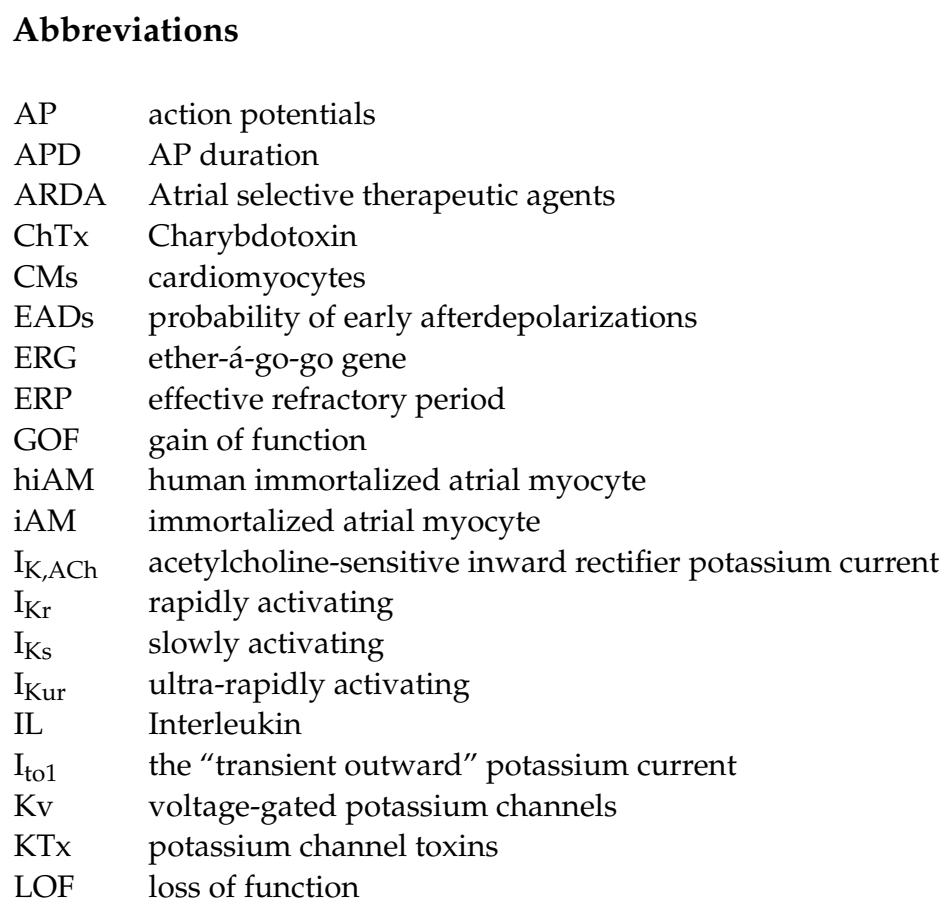




$\begin{array}{ll}\text { MgTx } & \text { Margatoxin } \\ \text { PAH } & \text { pulmonary arterial hypertension } \\ \text { ProTx2 } & \text { Protoxin II } \\ \text { SPPS } & \text { solid-phase peptide synthesis } \\ \text { SR } & \text { sinus rhythm } \\ \text { TTX } & \text { tetrodotoxin } \\ \text { VGICs } & \text { Voltage-gated ion channels } \\ \text { Vmax }_{\text {max }} & \text { maximum speed of depolarization } \\ \text { VSD } & \text { voltage-sensing domain } \\ \text { VSP } & \text { voltage-sensing phosphatase }\end{array}$

\section{References}

1. Alexander, S.P.; Catterall, W.A.; Kelly, E.; Marrion, N.; Peters, J.A.; Benson, H.E.; Faccenda, E.; Pawson, A.J.; Sharman, J.L.; Southan, C.; et al. The Concise Guide to PHARMACOLOGY 2015/16: Voltage-gated ion channels. Br. J. Pharmacol. 2015, 172, 5904-5941. [CrossRef]

2. Yellen, G. The moving parts of voltage-gated ion channels. Q. Rev. Biophys. 1998, 31, 239-295. [CrossRef]

3. Swartz, K.J. Sensing voltage across lipid membranes. Nature 2008, 456, 891-897. [CrossRef]

4. DeCoursey, T. The Voltage-Gated Proton Channel: A Riddle, Wrapped in a Mystery, inside an Enigma. Biochemistry 2015, 54, 3250-3268. [CrossRef]

5. Murata, Y.; Iwasaki, H.; Sasaki, M.; Inaba, K.; Okamura, Y. Phosphoinositide phosphatase activity coupled to an intrinsic voltage sensor. Nature 2005, 435, 1239-1243. [CrossRef]

6. Ramsey, I.S.; Moran, M.M.; Chong, J.A.; Clapham, D.E. A voltage-gated proton-selective channel lacking the pore domain. Nature 2006, 440, 1213-1216. [CrossRef]

7. Sasaki, M.; Takagi, M.; Okamura, Y. A Voltage Sensor-Domain Protein Is a Voltage-Gated Proton Channel. Science 2006, 312, 589-592. [CrossRef]

8. Gutman, G.A.; Chandy, K.G.; Grissmer, S.; Lazdunski, M.; McKinnon, D.; Pardo, L.; Robertson, G.A.; Rudy, B.; Sanguinetti, M.C.; Stühmer, W.; et al. International Union of Pharmacology. LIII. Nomenclature and Molecular Relationships of Voltage-Gated Potassium Channels. Pharmacol. Rev. 2005, 57, 473-508. [CrossRef]

9. Snyders, D.J. Structure and function of cardiac potassium channels. Cardiovasc. Res. 1999, 42, 377-390. [CrossRef]

10. Fedida, D.; Wible, B.; Wang, Z.; Fermini, B.; Faust, F.; Nattel, S.; Brown, A.M. Identity of a novel delayed rectifier current from human heart with a cloned $\mathrm{K}^{+}$channel current. Circ. Res. 1993, 73, 210-216. [CrossRef]

11. Brunner, M.; Kodirov, S.; Mitchell, G.F.; Buckett, P.D.; Shibata, K.; Folco, E.J.; Baker, L.; Salama, G.; Chan, D.P.; Zhou, J.; et al. In vivo gene transfer of Kv1.5 normalizes action potential duration and shortens QT interval in mice with long QT phenotype. Am. J. Physiol. Circ. Physiol. 2003, 285, H194-H203. [CrossRef]

12. Guo, X.; Chen, W.; Sun, H.; You, Q. Kv1.5 Inhibitors for Treatment of Atrial Fibrillation: A Tradeoff between Selectivity and Non-selectivity. Curr. Top. Med. Chem. 2016, 16, 1843-1854. [CrossRef]

13. Lip, G.Y.; Tse, H.F. Management of atrial fibrillation. Lancet 2007, 370, 604-618. [CrossRef]

14. Ehrlich, J.R.; Biliczki, P.; Hohnloser, S.H.; Nattel, S. Atrial-Selective Approaches for the Treatment of Atrial Fibrillation. J. Am. Coll. Cardiol. 2008, 51, 787-792. [CrossRef]

15. Ford, J.W.; Milnes, J.T. New drugs targeting the cardiac ultra-rapid delayed-rectifier current (I Kur): Rationale, pharmacology and evidence for potential therapeutic value. J. Cardiovasc. Pharmacol. 2008, 52, 105-120. [CrossRef]

16. Ehrlich, J.R.; Nattel, S. Novel Approaches for Pharmacological Management of Atrial Fibrillation. Drugs 2009, 69, 757-774. [CrossRef] [PubMed]

17. Ravens, U. Antiarrhythmic therapy in atrial fibrillation. Pharmacol. Ther. 2010, 128, 129-145. [CrossRef] [PubMed]

18. Olson, T.M.; Alekseev, A.E.; Liu, X.K.; Park, S.; Zingman, L.; Bienengraeber, M.; Sattiraju, S.; Ballew, J.D.; Jahangir, A.; Terzic, A. Kv1.5 channelopathy due to KCNA5 loss-of-function mutation causes human atrial fibrillation. Hum. Mol. Genet. 2006, 15, 2185-2191. [CrossRef]

19. Christophersen, I.E.; Olesen, M.S.; Liang, B.; Andersen, M.N.; Larsen, A.P.; Nielsen, J.B.; Haunsø, S.; Olesen, S.-P.; Tveit, A.; Svendsen, J.H.; et al. Genetic variation in KCNA5: Impact on the atrial-specific potassium current $\mathrm{I}_{\text {Kur }}$ in patients with lone atrial fibrillation. Eur. Heart J. 2013, 34, 1517-1525. [CrossRef]

20. Remillard, C.V.; Tigno, D.D.; Platoshyn, O.; Burg, E.D.; Brevnova, E.E.; Conger, D.; Nicholson, A.; Rana, B.K.; Channick, R.N.; Rubin, L.J.; et al. Function of Kv1.5 channels and genetic variations ofKCNA5in patients with idiopathic pulmonary arterial hypertension. Am. J. Physiol.-Cell Physiol. 2007, 292, C1837-C1853. [CrossRef]

21. Fu, L.; Lv, Y.; Zhong, Y.; He, Q.; Liu, X.; Du, L. Tyrosine phosphorylation of Kv1.5 is upregulated in intrauterine growth retardation rats with exaggerated pulmonary hypertension. Braz. J. Med. Biol. Res. 2017, 50, e6237. [CrossRef]

22. Macfarlane, S.N.; Sontheimer, H. Modulation of Kv1.5 Currents by Src Tyrosine Phosphorylation: Potential Role in the Differentiation of Astrocytes. J. Neurosci. 2000, 20, 5245-5253. [CrossRef] [PubMed]

23. Preussat, K.; Beetz, C.; Schrey, M.; Kraft, R.; Wölfl, S.; Kalff, R.; Patt, S. Expression of voltage-gated potassium channels Kv1.3 and Kv1.5 in human gliomas. Neurosci. Lett. 2003, 346, 33-36. [CrossRef] 
24. Bielanska, J.; Hernandez-Losa, J.; Perez-Verdaguer, M.; Moline, T.; Somoza, R.; Cajal, S.R.Y.; Condom, E.; Ferreres, J.C.; Felipe, A. Voltage-dependent potassium channels Kv1.3 and Kv1.5 in human cancer. Curr. Cancer Drug Targets 2009, 9, 904-914. [CrossRef] [PubMed]

25. Vallejo-Gracia, A.; Bielanska, J.; Hernández-Losa, J.; Castellví, J.; Ruiz-Marcellan, M.C.; Cajal, S.R.Y.; Condom, E.; Manils, J.; Soler, C.; Comes, N.; et al. Emerging role for the voltage-dependent $\mathrm{K}^{+}$channel Kv1.5 in B-lymphocyte physiology: Expression associated with human lymphoma malignancy. J. Leukoc. Biol. 2013, 94, 779-789. [CrossRef]

26. Chung, M.K.; Eckhardt, L.L.; Chen, L.Y.; Ahmed, H.M.; Gopinathannair, R.; Joglar, J.A.; Noseworthy, P.A.; Pack, Q.R.; Sanders, P.; Trulock, K.M. Lifestyle and Risk Factor Modification for Reduction of Atrial Fibrillation: A Scientific Statement from the American Heart Association. Circulation 2020, 141, e750-e772. [CrossRef]

27. Conen, D. Epidemiology of atrial fibrillation. Eur. Heart J. 2018, 39, 1323-1324. [CrossRef] [PubMed]

28. Wettwer, E.; Terlau, H. Pharmacology of voltage-gated potassium channel Kv1.5-Impact on cardiac excitability. Curr. Opin. Pharmacol. 2014, 15, 115-121. [CrossRef]

29. Attali, B.; Chandy, K.G.; Giese, M.H.; Grissmer, S.; Gutman, G.A.; Jan, L.Y.; Lazdunski, M.; McKinnon, D.; Nerbonne, J.; Pardo, L.A.; et al. Voltage-gated potassium channels (version 2019.4) in the IUPHAR/BPS Guide to Pharmacology Database. IUPHAR/BPS Guide Pharmacol. CITE 2019, 2019. [CrossRef]

30. Bajaj, S.; Han, J. Venom-Derived Peptide Modulators of Cation-Selective Channels: Friend, Foe or Frenemy. Front. Pharmacol. 2019, 10, 58. [CrossRef]

31. Wirth, K.J.; Paehler, T.; Rosenstein, B.; Knobloch, K.; Maier, T.; Frenzel, J.; Brendel, J.; Busch, A.E.; Bleich, M. Atrial effects of the novel $\mathrm{K}^{+}$-channel-blocker AVE0118 in anesthetized pigs. Cardiovasc. Res. 2003, 60, 298-306. [CrossRef]

32. Christ, T.; Wettwer, E.; Voigt, N.; Hála, O.; Radicke, S.; Matschke, K.; Várro, A.; Dobrev, D.; Ravens, U. Pathology-specific effects of the $\mathrm{I}_{\mathrm{Kur}} / \mathrm{I}_{\mathrm{to}} / \mathrm{I}_{\mathrm{K}, \mathrm{ACh}}$ blocker AVE0118 on ion channels in human chronic atrial fibrillation. Br. J. Pharmacol. 2008, 154, 1619-1630. [CrossRef]

33. Wettwer, E.; Hála, O.; Christ, T.; Heubach, J.F.; Dobrev, D.; Knaut, M.; Varró, A.; Ravens, U. Role of IKur in controlling action potential shape and contractility in the human atrium: Influence of chronic atrial fibrillation. Circulation 2004, 110, 2299-2306. [CrossRef]

34. Wirth, K.J.; Steinmeyer, K.; Ruetten, H. Sensitization of Upper Airway Mechanoreceptors as a New Pharmacologic Principle to Treat Obstructive Sleep Apnea: Investigations with AVE0118 in Anesthetized Pigs. Sleep 2013, 36, 699-708. [CrossRef] [PubMed]

35. Shunmugam, S.R.; Sugihara, C.; Freemantle, N.; Round, P.; Furniss, S.; Sulke, N. A double-blind, randomised, placebo-controlled, cross-over study assessing the use of XEN-D0103 in patients with paroxysmal atrial fibrillation and implanted pacemakers allowing continuous beat-to-beat monitoring of drug efficacy. J. Interv. Card. Electrophysiol. 2018, 51, 191-197. [CrossRef]

36. Lagrutta, A.; Wang, J.; Fermini, B.; Salata, J.J. Novel, potent inhibitors of human Kv1.5 K ${ }^{+}$channels and ultrarapidly activating delayed rectifier potassium current. J. Pharmacol. Exp. Ther. 2006, 317, 1054-1063. [CrossRef] [PubMed]

37. Fedida, D.; Orth, P.M.; Chen, J.Y.; Lin, S.; Plouvier, B.; Jung, G.; Ezrin, A.M.; Beatch, G.N. The Mechanism of Atrial Antiarrhythmic Action of RSD1235. J. Cardiovasc. Electrophysiol. 2005, 16, 1227-1238. [CrossRef]

38. Wettwer, E.; Christ, T.; Endig, S.; Rozmaritsa, N.; Matschke, K.; Lynch, J.J.; Pourrier, M.; Gibson, J.K.; Fedida, D.; Knaut, M.; et al. The new antiarrhythmic drug vernakalant: Ex vivo study of human atrial tissue from sinus rhythm and chronic atrial fibrillation. Cardiovasc. Res. 2013, 98, 145-154. [CrossRef]

39. Dobrev, D.; Hamad, B.; Kirkpatrick, P. Vernakalant. Nat. Rev. Drug Discov. 2010, 9, 915-916. [CrossRef]

40. Burashnikov, A.; Pourrier, M.; Gibson, J.K.; Lynch, J.J.; Antzelevitch, C. Rate-dependent effects of vernakalant in the isolated non-remodeled canine left atria are primarily due to block of the sodium channel: Comparison with ranolazine and dl-sotalol. Circ. Arrhythmia Electrophysiol. 2012, 5, 400-408. [CrossRef]

41. van Middendorp, L.B.; Strik, M.; Houthuizen, P.; Kuiper, M.; Maessen, J.G.; Auricchio, A.; Prinzen, F.W. Electrophysiological and haemodynamic effects of vernakalant and flecainide in dyssynchronous canine hearts. Europace 2014, 16, 1249-1256. [CrossRef] [PubMed]

42. Camm, A.J.; Capucci, A.; Hohnloser, S.H.; Torp-Pedersen, C.; Van Gelder, I.C.; Mangal, B.; Beatch, G. A Randomized ActiveControlled Study Comparing the Efficacy and Safety of Vernakalant to Amiodarone in Recent-Onset Atrial Fibrillation. J. Am. Coll. Cardiol. 2011, 57, 313-321. [CrossRef] [PubMed]

43. Cialdella, P.; Pedicino, D.; Santangeli, P. Novel Agents for the Acute Conversion of Atrial Fibrillation: Focus on Vernakalant. Recent Patents Cardiovasc. Drug Discov. 2011, 6, 1-8. [CrossRef] [PubMed]

44. Simon, A.; Niederdoeckl, J.; Janata, K.; Spiel, A.O.; Schuetz, N.; Schnaubelt, S.; Herkner, H.; Cacioppo, F.; Laggner, A.N.; Domanovits, H. Vernakalant and electrical cardioversion for AF-Safe and effective. IJC Heart Vasc. 2019, 24, 100398. [CrossRef]

45. Hall, A.J.; Mitchell, A. Introducing Vernakalant into Clinical Practice. Arrhythmia Electrophysiol. Rev. 2019, 8, 70-74. [CrossRef]

46. Bergeron, Z.L.; Bingham, J.P. Scorpion toxins specific for potassium $\left(\mathrm{K}^{+}\right)$channels: A historical overview of peptide bioengineering. Toxins 2012, 4, 1082-1119. [CrossRef]

47. Rash, L.; Hodgson, W.C. Pharmacology and biochemistry of spider venoms. Toxicon 2002, 40, 225-254. [CrossRef]

48. King, G.F.; Gentz, M.C.; Escoubas, P.; Nicholson, G.M. A rational nomenclature for naming peptide toxins from spiders and other venomous animals. Toxicon 2008, 52, 264-276. [CrossRef]

49. Jungo, F.; Bairoch, A. Tox-Prot, the toxin protein annotation program of the Swiss-Prot protein knowledgebase. Toxicon 2005, 45, 293-301. [CrossRef] 
50. Jungo, F.; Estreicher, A.; Bairoch, A.; Bougueleret, L.; Xenarios, I. Animal Toxins: How is Complexity Represented in Databases? Toxins 2010, 2, 262-282. [CrossRef]

51. Jungo, F.; Bougueleret, L.; Xenarios, I.; Poux, S. The UniProtKB/Swiss-Prot Tox-Prot program: A central hub of integrated venom protein data. Toxicon 2012, 60, 551-557. [CrossRef] [PubMed]

52. Quintero-Hernández, V.; Jiménez-Vargas, J.; Gurrola, G.; Valdivia, H.; Possani, L. Scorpion venom components that affect ion-channels function. Toxicon 2013, 76, 328-342. [CrossRef]

53. Kuzmenkov, A.I.; Krylov, N.; Chugunov, A.O.; Grishin, E.V.; Vassilevski, A.A. Kalium: A database of potassium channel toxins from scorpion venom. Database 2016, 2016, baw056. [CrossRef]

54. Tytgat, J.; Chandy, K.G.; Garcia, M.L.; Gutman, G.A.; Martin-Eauclaire, M.F.; van der Walt, J.J.; Possani, L.D. A unified nomenclature for short-chain peptides isolated from scorpion venoms: Alpha-KTx molecular subfamilies. Trends Pharmacol. Sci. 1999, 20, 444-447. [CrossRef]

55. de la Vega, R.C.R.; Possani, L.D. Current views on scorpion toxins specific for $\mathrm{K}^{+}$-channels. Toxicon 2004, 43, 865-875. [CrossRef]

56. Zhu, S.; Gao, B.; Aumelas, A.; Rodríguez, M.D.C.; Lanz-Mendoza, H.; Peigneur, S.; Diego-Garcia, E.; Martin-Eauclaire, M.-F.; Tytgat, J.; Possani, L.D. MeuTXK $\beta 1$, a scorpion venom-derived two-domain potassium channel toxin-like peptide with cytolytic activity. Biochim. Biophys. Acta (BBA)-Proteins Proteom. 2010, 1804, 872-883. [CrossRef]

57. Kuzmenkov, A.I.; Grishin, E.V.; Vassilevski, A.A. Diversity of Potassium Channel Ligands: Focus on Scorpion Toxins. Biochemistry 2015, 80, 1764-1799. [CrossRef] [PubMed]

58. Bartok, A.; Panyi, G.; Varga, Z. Potassium Channel Blocking Peptide Toxins from Scorpion Venom. In Scorpion Venoms; Springer: Dordrecht, The Netherlands, 2015; pp. 493-527.

59. Diego-García, E.; Schwartz, E.F.; D’Suze, G.; González, S.A.R.; Batista, C.V.; García, B.I.; de la Vega, R.C.R.; Possani, L.D. Wide phylogenetic distribution of Scorpine and long-chain beta-KTx-like peptides in scorpion venoms: Identification of "orphan" components. Peptides 2007, 28, 31-37. [CrossRef] [PubMed]

60. Jiménez-Vargas, J.; Restano-Cassulini, R.; Possani, L. Toxin modulators and blockers of hERG K ${ }^{+}$channels. Toxicon 2012, 60, 492-501. [CrossRef]

61. Corona, M.; Gurrola, G.B.; Merino, E.; Cassulini, R.R.; Valdez-Cruz, N.A.; García, B.; Ramírez-Domínguez, M.E.; Coronas, F.I.; Zamudio, F.Z.; Wanke, E.; et al. A large number of novel Ergtoxin-like genes and ERG $\mathrm{K}^{+}$-channels blocking peptides from scorpions of the genus Centruroides. FEBS Lett. 2002, 532, 121-126. [CrossRef]

62. Chagot, B.; Pimentel, C.; Dai, L.; Pil, J.; Tytgat, J.; Nakajima, T.; Corzo, G.; Darbon, H.; Ferrat, G. An unusual fold for potassium channel blockers: NMR structure of three toxins from the scorpion Opisthacanthus madagascariensis. Biochem. J. 2005, 388, 263-271. [CrossRef] [PubMed]

63. Zhao, R.; Dai, H.; Qiu, S.; Li, T.; He, Y.; Ma, Y.; Chen, Z.; Wu, Y.; Li, W.; Cao, Z. SdPI, The First Functionally Characterized Kunitz-Type Trypsin Inhibitor from Scorpion Venom. PLoS ONE 2011, 6, e27548. [CrossRef]

64. Chen, Z.-Y.; Hu, Y.-T.; Yang, W.-S.; He, Y.-W.; Feng, J.; Wang, B.; Zhao, R.-M.; Ding, J.-P.; Cao, Z.-J.; Li, W.-X.; et al. Hg1, Novel Peptide Inhibitor Specific for Kv1.3 Channels from First Scorpion Kunitz-type Potassium Channel Toxin Family. J. Biol. Chem. 2012, 287, 13813-13821. [CrossRef] [PubMed]

65. Cremonez, C.M.; Maiti, M.; Peigneur, S.; Cassoli, J.S.; Dutra, A.A.A.; Waelkens, E.; Lescrinier, E.; Herdewijn, P.; De Lima, M.E.; Pimenta, A.M.C.; et al. Structural and Functional Elucidation of Peptide Ts11 Shows Evidence of a Novel Subfamily of Scorpion Venom Toxins. Toxins 2016, 8, 288. [CrossRef] [PubMed]

66. Jiménez-Vargas, J.M.; Possani, L.D.; Luna-Ramírez, K. Arthropod toxins acting on neuronal potassium channels. Neuropharmacology 2017, 127, 139-160. [CrossRef]

67. Gao, B.; Harvey, P.J.; Craik, D.J.; Ronjat, M.; De Waard, M.; Zhu, S. Functional evolution of scorpion venom peptides with an inhibitor cystine knot fold. Biosci. Rep. 2013, 33, 513-527. [CrossRef]

68. Banerjee, A.; Lee, A.; Campbell, E.B.; MacKinnon, R. Structure of a pore-blocking toxin in complex with a eukaryotic voltagedependent $\mathrm{K}^{+}$channel. eLife 2013, 2, e00594. [CrossRef]

69. Mouhat, S.; Mosbah, A.; Visan, V.; Wulff, H.; Delepierre, M.; Darbon, H.; Grissmer, S.; De Waard, M.; Sabatier, J.-M. The functional dyad of scorpion toxin Pi1 is not itself a prerequisite for toxin binding to the voltage-gated Kv1.2 potassium channels. Biochem. J. 2004, 377, 25-36. [CrossRef] [PubMed]

70. Cui, M.; Shen, J.; Briggs, J.M.; Fu, W.; Wu, J.; Zhang, Y.; Luo, X.; Chi, Z.; Ji, R.; Jiang, H.; et al. Brownian dynamics simulations of the recognition of the scorpion toxin P05 with the small-conductance calcium-activated potassium channels. J. Mol. Biol. 2002, 318, 417-428. [CrossRef]

71. Pardo-Lopez, L.; Zhang, M.; Liu, J.; Jiang, M.; Possani, L.D.; Tseng, G.N. Mapping the binding site of a human ether-a-go-gorelated gene-specific peptide toxin (ErgTx) to the channel's outer vestibule. J. Mol. Biol. 2002, 277, 16403-16411.

72. Li-Smerin, Y.; Swartz, K.J. Gating modifier toxins reveal a conserved structural motif in voltage-gated $\mathrm{Ca}^{2+}$ and $\mathrm{K}^{+}$channels. Proc. Natl. Acad. Sci. USA 1998, 95, 8585-8589. [CrossRef] [PubMed]

73. Sanguinetti, M.C.; Johnson, J.H.; Hammerland, L.G.; Kelbaugh, P.R.; Volkmann, R.A.; Saccomano, N.A.; Mueller, A.L. Heteropodatoxins: Peptides isolated from spider venom that block Kv4.2 potassium channels. Mol. Pharmacol. 1997, 51, 491-498. [PubMed] 
74. Redaelli, E.; Cassulini, R.R.; Silva, D.F.; Clement, H.; Schiavon, E.; Zamudio, F.Z.; Odell, G.; Arcangeli, A.; Clare, J.J.; Alagón, A.; et al. Target Promiscuity and Heterogeneous Effects of Tarantula Venom Peptides Affecting $\mathrm{Na}^{+}$and $\mathrm{K}^{+}$Ion Channels. J. Biol. Chem. 2010, 285, 4130-4142. [CrossRef]

75. Diochot, S.; Drici, M.-D.; Moinier, D.; Fink, M.; Lazdunski, M. Effects of phrixotoxins on the Kv4 family of potassium channels and implications for the role of $\mathrm{I}_{\mathrm{to} 1}$ in cardiac electrogenesis. Br. J. Pharmacol. 1999, 126, 251-263. [CrossRef] [PubMed]

76. Park, J.H.; Carlin, K.P.; Wu, G.; Ilyin, V.I.; Musza, L.L.; Blake, P.R.; Kyle, D.J. Studies Examining the Relationship between the Chemical Structure of Protoxin II and Its Activity on Voltage Gated Sodium Channels. J. Med. Chem. 2014, 57, 6623-6631. [CrossRef]

77. Escoubas, P.; Diochot, S.; Célérier, M.L.; Nakajima, T.; Lazdunski, M. Novel tarantula toxins for subtypes of voltage-dependent potassium channels in the Kv2 and Kv4 subfamilies. Mol. Pharmacol. 2002, 62, 48-57. [CrossRef]

78. Osteen, J.D.; Herzig, V.; Gilchrist, J.; Emrick, J.J.; Zhang, C.; Wang, X.; Castro, J.; Garcia-Caraballo, S.; Grundy, L.; Rychkov, G.Y.; et al. Selective spider toxins reveal a role for the Nav1.1 channel in mechanical pain. Nature 2016, 534, 494-499. [CrossRef]

79. Montandon, G.G.; Cassoli, J.S.; Peigneur, S.; Verano-Braga, T.; dos Santos, D.M.; Paiva, A.L.B.; de Moraes, É.R.; Kushmerick, C.; Borges, M.H.; Richardson, M.; et al. GiTx1( $\beta / \kappa$-theraphotoxin-Gi1a), a novel toxin from the venom of Brazilian tarantula Grammostola iheringi (Mygalomorphae, Theraphosidae): Isolation, structural assessments and activity on voltage-gated ion channels. Biochimie 2020, 176, 138-149. [CrossRef]

80. Lee, S.-Y.; MacKinnon, R. A membrane-access mechanism of ion channel inhibition by voltage sensor toxins from spider venom. Nature 2004, 430, 232-235. [CrossRef]

81. Wee, C.L.; Bemporad, D.; Sands, Z.A.; Gavaghan, D.; Sansom, M.S. SGTx1, a Kv Channel Gating-Modifier Toxin, Binds to the Interfacial Region of Lipid Bilayers. Biophys. J. 2007, 92, L07-L09. [CrossRef]

82. Wang, Y.; Luo, Z.; Lei, S.; Li, S.; Li, X.; Yuan, C. Effects and mechanism of gating modifier spider toxins on the hERG channel. Toxicon 2021, 189, 56-64. [CrossRef] [PubMed]

83. Saez, N.J.; Senff, S.; Jensen, J.E.; Er, S.Y.; Herzig, V.; Rash, L.D.; King, G.F. Spider-Venom Peptides as Therapeutics. Toxins 2010, 2, 2851-2871. [CrossRef]

84. Colgrave, M.L.; Craik, D.J. Thermal, Chemical, and Enzymatic Stability of the Cyclotide Kalata B1: The Importance of the Cyclic Cystine Knot. Biochemistry 2004, 43, 5965-5975. [CrossRef] [PubMed]

85. Swartz, K.J. Tarantula toxins interacting with voltage sensors in potassium channels. Toxicon 2007, 49, 213-230. [CrossRef]

86. Ozawa, S.-I.; Kimura, T.; Nozaki, T.; Harada, H.; Shimada, I.; Osawa, M. Structural basis for the inhibition of voltage-dependent $\mathrm{K}^{+}$channel by gating modifier toxin. Sci. Rep. 2015, 5, 14226. [CrossRef] [PubMed]

87. Li-Smerin, Y.; Swartz, K.J. Localization and Molecular Determinants of the Hanatoxin Receptors on the Voltage-Sensing Domains of a $\mathrm{K}^{+}$Channel. J. Gen. Physiol. 2000, 115, 673-684. [CrossRef]

88. Tao, H.; Chen, X.; Deng, M.; Xiao, Y.; Wu, Y.; Liu, Z.; Zhou, S.; He, Y.; Liang, S. Interaction site for the inhibition of tarantula Jingzhaotoxin-XI on voltage-gated potassium channel Kv2.1. Toxicon 2016, 124, 8-14. [CrossRef]

89. DeSimone, C.V.; Lu, Y.; Bondarenko, V.E.; Morales, M.J. S3b Amino Acid Substitutions and Ancillary Subunits Alter the Affinity of Heteropoda venatoria Toxin 2 for Kv4.3. Mol. Pharmacol. 2009, 76, 125-133. [CrossRef] [PubMed]

90. Ebbinghaus, J.; Legros, C.; Nolting, A.; Guette, C.; Celerier, M.-L.; Pongs, O.; Bähring, R. Modulation of Kv4.2 channels by a peptide isolated from the venom of the giant bird-eating tarantula Theraphosa leblondi. Toxicon 2004, 43, 923-932. [CrossRef]

91. Alvarado, D.; Cardoso-Arenas, S.; Corrales-García, L.-L.; Clement, H.; Arenas, I.; Montero-Dominguez, P.A.; Olamendi-Portugal, T.; Zamudio, F.; Csoti, A.; Borrego, J.; et al. A Novel Insecticidal Spider Peptide that Affects the Mammalian Voltage-Gated Ion Channel hKv1.5. Front. Pharmacol. 2021, 11, 1937. [CrossRef]

92. Cerni, F.A.; Pucca, M.B.; Peigneur, S.; Cremonez, C.M.; Bordon, K.C.F.; Tytgat, J.; Arantes, E.C. Electrophysiological Characterization of Ts6 and Ts7, $\mathrm{K}^{+}$Channel Toxins Isolated through an Improved Tityus serrulatus Venom Purification Procedure. Toxins 2014, 6, 892-913. [CrossRef]

93. Martin-Eauclaire, M.F.; Pimenta, A.M.; Bougis, P.E.; De Lima, M.E. Potassium channel blockers from the venom of the Brazilian scorpion Tityus serrulatus (Lutz and Mello, 1922). Toxicon 2016, 119, 253-265. [CrossRef] [PubMed]

94. Zoccal, K.F.; da Silva Bitencourt, C.; Sorgi, C.A.; Bordon, K.D.C.F.; Sampaio, S.V.; Arantes, E.C.; Faccioli, L.H. Ts6 and Ts2 from Tityus serrulatus venom induce inflammation by mechanisms dependent on lipid mediators and cytokine production. Toxicon 2013, 61, 1-10. [CrossRef]

95. Zoccal, K.F.; Bitencourt, C.D.S.; Secatto, A.; Sorgi, C.A.; Bordon, K.D.C.F.; Sampaio, S.V.; Arantes, E.C.; Faccioli, L.H. Tityus serrulatus venom and toxins Ts1, Ts2 and Ts6 induce macrophage activation and production of immune mediators. Toxicon 2011, 57, 1101-1108. [CrossRef] [PubMed]

96. Lazzerini, P.E.; Laghi-Pasini, F.; Acampa, M.; Srivastava, U.; Bertolozzi, I.; Giabbani, B.; Finizola, F.; Vanni, F.; Dokollari, A.; Natale, M.; et al. Systemic Inflammation Rapidly Induces Reversible Atrial Electrical Remodeling: The Role of Interleukin-6Mediated Changes in Connexin Expression. J. Am. Heart Assoc. 2019, 8, e011006. [CrossRef] [PubMed]

97. Loose, S.; MUller, J.; Wettwer, E.; El-Haou, S.; Jackson, C.; Tang, R.; Milnes, J.; Ravens, U.; Ford, J. Abstract 18323: Positive Frequency-Dependent Effects of Highly Selective Kv1.5 Blockers (XEN-D0103 \& MK-0448) in Right Atrial Trabeculae from Patients in Sinus Rhythm. Circulation 2013, 128, A18323. 
98. Varga, Z.; Gurrola-Briones, G.; Papp, F.; de la Vega, R.C.R.; Pedraza-Alva, G.; Tajhya, R.B.; Gaspar, R.; Cardenas, L.; Rosenstein, Y.; Beeton, C.; et al. Vm24, a Natural Immunosuppressive Peptide, Potently and Selectively Blocks Kv1.3 Potassium Channels of Human T Cells. Mol. Pharmacol. 2012, 82, 372-382. [CrossRef]

99. Furman, B. Tetraethylammonium. In Reference Module in Biomedical Sciences; Elsevier: Amsterdam, The Netherlands, 2018.

100. Schmitz, A.; Sankaranarayanan, A.; Azam, P.; Schmidt-Lassen, K.; Homerick, D.; Hänsel, W.; Wulff, H. Design of PAP-1, a Selective Small Molecule Kv1.3 Blocker, for the Suppression of Effector Memory T Cells in Autoimmune Diseases. Mol. Pharmacol. 2005, 68, 1254-1270. [CrossRef] [PubMed]

101. Lee, C.H.; Ruben, P.C. Interaction between voltage-gated sodium channels and the neurotoxin, tetrodotoxin. Channels 2008, 2, 407-412. [CrossRef]

102. Ahuja, S.; Mukund, S.; Deng, L.; Khakh, K.; Chang, E.; Ho, H.; Shriver, S.; Young, C.; Lin, S.; Johnson, J.P.; et al. Structural basis of Nav1.7 inhibition by an isoform-selective small-molecule antagonist. Science 2015, 350, aac5464. [CrossRef]

103. Gilquin, B.; Braud, S.; Eriksson, M.A.L.; Roux, B.; Bailey, T.D.; Priest, B.T.; Garcia, M.L.; Ménez, A.; Gasparini, S. A Variable Residue in the Pore of Kv1 Channels Is Critical for the High Affinity of Blockers from Sea Anemones and Scorpions. J. Biol. Chem. 2005, 280, 27093-27102. [CrossRef]

104. Zhu, J.; Gomez, B.; Watanabe, I.; Thornhill, W.B. Amino acids in the pore region of Kv1 potassium channels dictate cell-surface protein levels: A possible trafficking code in the Kv1 subfamily. Biochem. J. 2005, 388, 355-362. [CrossRef]

105. Li, S.; Sunchen, S.; He, D.; Qin, C.; Zuo, Z.; Shen, B.; Cao, Z.; Hong, W.; Miao, L. ImKTx96, a peptide blocker of the Kv1.2 ion channel from the venom of the scorpion Isometrus maculates. Peptides 2019, 123, 170172. [CrossRef]

106. Lin, S.; Wang, X.; Hu, X.; Zhao, Y.; Zhao, M.; Zhang, J.; Cui, Y. Recombinant Expression, Functional Characterization of Two Scorpion Venom Toxins with Three Disulfide Bridges from the Chinese Scorpion Buthus martensii Karsch. Protein Pept. Lett. 2017, 24, 235-240. [CrossRef] [PubMed]

107. Naseem, M.U.; Tajti, G.; Gaspar, A.; Szanto, T.G.; Borrego, J.; Panyi, G. Optimization of Pichia pastoris Expression System for High-Level Production of Margatoxin. Front. Pharmacol. 2021, 12, 733610. [CrossRef] [PubMed]

108. Geron, M. Production and Purification of Recombinant Toxins. In Snake and Spider Toxins; Humana: New York, NY, USA, 2020; pp. 73-84.

109. Lobstein, J.; Emrich, C.A.; Jeans, C.; Faulkner, M.; Riggs, P.; Berkmen, M. SHuffle, a novel Escherichia coli protein expression strain capable of correctly folding disulfide bonded proteins in its cytoplasm. Microb. Cell Factories 2012, 11, 56. [CrossRef] [PubMed]

110. Bessette, P.H.; Åslund, F.; Beckwith, J.; Georgiou, G. Efficient folding of proteins with multiple disulfide bonds in the Escherichia coli cytoplasm. Proc. Natl. Acad. Sci. USA 1999, 96, 13703. [CrossRef] [PubMed]

111. Klint, J.; Senff, S.; Saez, N.; Seshadri, R.; Lau, H.Y.; Bende, N.S.; Undheim, E.; Rash, L.; Mobli, M.; King, G.F. Production of Recombinant Disulfide-Rich Venom Peptides for Structural and Functional Analysis via Expression in the Periplasm of E. coli. PLoS ONE 2013, 8, e63865. [CrossRef]

112. De Marco, A. Strategies for successful recombinant expression of disulfide bond-dependent proteins in Escherichia coli. Microb. Cell Factories 2009, 8, 26. [CrossRef]

113. Demain, A.L.; Vaishnav, P. Production of recombinant proteins by microbes and higher organisms. Biotechnol. Adv. 2009, 27, 297-306. [CrossRef]

114. De-Bona, E.; Chaves-Moreira, D.; Batista, T.B.D.; da Justa, H.C.; Rossi, G.R.; Antunes, B.C.; Matsubara, F.H.; Minozzo, J.C.; Wille, A.C.M.; Veiga, S.S.; et al. Production of a novel recombinant brown spider hyaluronidase in baculovirus-infected insect cells. Enzym. Microb. Technol. 2021, 146, 109759. [CrossRef]

115. Szolajska, E.; Poznanski, J.; Ferber, M.L.; Michalik, J.; Gout, E.; Fender, P.; Bailly, I.; Dublet, B.; Chroboczek, J. Poneratoxin, a neurotoxin from ant venom. Structure and expression in insect cells and construction of a bio-insecticide. Eur. J. Biochem. 2004, 271, 2127-2136. [CrossRef] [PubMed]

116. Borgia, J.A.; Fields, G.B. Chemical synthesis of proteins. Trends Biotechnol. 2000, 18, 243-251. [CrossRef]

117. Jensen, J.E.; Durek, T.; Alewood, P.F.; Adams, D.J.; King, G.F.; Rash, L.D. Chemical synthesis and folding of APETx2, a potent and selective inhibitor of acid sensing ion channel 3. Toxicon 2009, 54, 56-61. [CrossRef]

118. Postma, T.M.; Albericio, F. Disulfide Formation Strategies in Peptide Synthesis. Eur. J. Org. Chem. 2014, 2014, 3519-3530. [CrossRef]

119. Shen, H.; Liu, D.; Wu, K.; Lei, J.; Yan, N. Structures of human Na v 1.7 channel in complex with auxiliary subunits and animal toxins. Science 2019, 363, 1303-1308. [CrossRef]

120. Xu, H.; Li, T.; Rohou, A.; Arthur, C.P.; Tzakoniati, F.; Wong, E.; Estevez, A.; Kugel, C.; Franke, Y.; Chen, J.; et al. Structural Basis of Nav1.7 Inhibition by a Gating-Modifier Spider Toxin. Cell 2019, 176, 702-715. [CrossRef] [PubMed]

121. Borrego, J.; Clement, H.; Corrales-García, L.-L.; Arenas, I.; Corzo, G. Key amino acid residues involved in mammalian and insecticidal activities of Magi4 and Hv1b, cysteine-rich spider peptides from the $\delta$-atracotoxin family. Amino Acids 2020, 52, 465-475. [CrossRef]

122. Netirojjanakul, C.; Miranda, L.P. Progress and challenges in the optimization of toxin peptides for development as pain therapeutics. Curr. Opin. Chem. Biol. 2017, 38, 70-79. [CrossRef]

123. Horovitz, A. Double-mutant cycles: A powerful tool for analyzing protein structure and function. Fold. Des. 1996, 1, R121-R126. [CrossRef] 
124. Kuyucak, S.; Norton, R.S. Computational approaches for designing potent and selective analogs of peptide toxins as novel therapeutics. Future Med. Chem. 2014, 6, 1645-1658. [CrossRef] [PubMed]

125. Nikouee, A.; Khabiri, M.; Grissmer, S.; Ettrich, R. Charybdotoxin and Margatoxin Acting on the Human Voltage-Gated Potassium Channel hKv1.3 and Its H399N Mutant: An Experimental and Computational Comparison. J. Phys. Chem. B 2012, 116, 5132-5140. [CrossRef] [PubMed]

126. Corzo, G.; Papp, F.; Varga, Z.; Barraza, O.; Espino-Solis, P.G.; de la Vega, R.C.R.; Gaspar, R.; Panyi, G.; Possani, L.D. A selective blocker of Kv1.2 and Kv1.3 potassium channels from the venom of the scorpion Centruroides suffusus suffusus. Biochem. Pharmacol. 2008, 76, 1142-1154. [CrossRef] [PubMed]

127. Gigolaev, A.M.; Kuzmenkov, A.I.; Peigneur, S.; Tabakmakher, V.; Pinheiro-Junior, E.; Chugunov, A.O.; Efremov, R.G.; Tytgat, J.; Vassilevski, A.A. Tuning Scorpion Toxin Selectivity: Switching From KV1.1 to KV1.3. Front. Pharmacol. 2020, 11, 1010. [CrossRef] [PubMed]

128. Tabakmakher, V.M.; Kuzmenkov, A.I.; Gigolaev, A.M.; Pinheiro-Junior, E.L.; Peigneur, S.; Efremov, R.G.; Tytgat, J.; Vassilevski, A.A. Artificial Peptide Ligand of PotassiumChannel KV1.1 with High Selectivity. J. Evol. Biochem. Physiol. 2021, 57, 386-403. [CrossRef]

129. Bartok, A.; Fehér, K.; Bodor, A.; Rákosi, K.; Tóth, G.K.; Kövér, K.E.; Panyi, G.; Varga, Z. An engineered scorpion toxin analogue with improved Kv1.3 selectivity displays reduced conformational flexibility. Sci. Rep. 2015, 5, 18397. [CrossRef] [PubMed]

130. Kuzmenkov, A.I.; Peigneur, S.; Chugunov, A.; Tabakmakher, V.; Efremov, R.G.; Tytgat, J.; Grishin, E.V.; Vassilevski, A.A. C-Terminal residues in small potassium channel blockers OdK1 and OSK3 from scorpion venom fine-tune the selectivity. Biochim. Biophys. Acta (BBA) Proteins Proteom. 2017, 1865, 465-472. [CrossRef]

131. Luna-Ramirez, K.; Csoti, A.; McArthur, J.R.; Chin, Y.K.; Anangi, R.; Najera, R.D.C.; Possani, L.D.; King, G.F.; Panyi, G.; Yu, H.; et al. Structural basis of the potency and selectivity of Urotoxin, a potent Kv1 blocker from scorpion venom. Biochem. Pharmacol. 2020, 174, 113782. [CrossRef]

132. Delgado-Prudencio, G.; Possani, L.D.; Becerril, B.; Ortiz, E. The Dual $\alpha$-Amidation System in Scorpion Venom Glands. Toxins 2019, 11, 425. [CrossRef]

133. Zhao, R.; Kennedy, K.; De Blas, G.A.; Orta, G.; Pavarotti, M.A.; Arias, R.J.; de la Vega-Beltrán, J.L.; Li, Q.; Dai, H.; Perozo, E.; et al. Role of human Hv1 channels in sperm capacitation and white blood cell respiratory burst established by a designed peptide inhibitor. Proc. Natl. Acad. Sci. USA 2018, 115, E11847-E11856. [CrossRef]

134. Erlanson, D.A. Introduction to Fragment-Based Drug Discovery. Top. Curr. Chem. 2011, 317, 1-32.

135. Price, A.J.; Howard, S.; Cons, B.D. Fragment-based drug discovery and its application to challenging drug targets. Essays Biochem. 2017, 61, 475-484. [PubMed]

136. Varga, Z.; Tajti, G.; Panyi, G. The Kv1.3 $\mathrm{K}^{+}$channel in the immune system and its "precision pharmacology" using peptide toxins. Biol. Futur. 2021, 72, 75-83. [CrossRef]

137. Shen, B.; Cao, Z.; Yingliang, W.; Sabatier, J.-M.; Wu, Y. Treating autoimmune disorders with venom-derived peptides. Expert Opin. Biol. Ther. 2017, 17, 1065-1075. [CrossRef]

138. Gubič, Š.; Hendrickx, L.A.; Toplak, Ž.; Sterle, M.; Peigneur, S.; Tomašič, T.; Pardo, L.A.; Tytgat, J.; Zega, A.; Mašič, L.P. Discovery of Kv1.3 ion channel inhibitors: Medicinal chemistry approaches and challenges. Med. Res. Rev. 2021, 41, 2423-2473. [CrossRef] [PubMed]

139. Liu, J.; Volkers, L.; Jangsangthong, W.; Bart, C.I.; Engels, M.C.; Zhou, G.; Schalij, M.J.; Ypey, D.L.; Pijnappels, D.A.; Vries, A.A.F.D. Generation and primary characterization of iAM-1, a versatile new line of conditionally immortalized atrial myocytes with preserved cardiomyogenic differentiation capacity. Cardiovasc. Res. 2018, 114, 1848-1859. [CrossRef]

140. Harlaar, N.; Liu, J.; Volkers, L.; Ramkisoensing, A.A.; Schalij, M.J.; Klautz, R.J.M.; Van Brakel, T.J.; Pijnappels, D.A.; Vries, A.A.F.D. P1229Massive expansion of native human atrial cardiomyocytes through immortogenetics: Generation of the hiAM cell lines. Eur. Heart J. 2019, 40, ehz748-0187. [CrossRef]

141. Laksman, Z.; Wauchop, M.; Lin, E.; Protze, S.; Lee, J.; Yang, W.; Izaddoustdar, F.; Shafaattalab, S.; Gepstein, L.; Tibbits, G.F.; et al. Modeling Atrial Fibrillation using Human Embryonic Stem Cell-Derived Atrial Tissue. Sci. Rep. 2017, 7, 1-11.

142. Barré-Sinoussi, F.; Montagutelli, X. Animal models are essential to biological research: Issues and perspectives. Future Sci. OA 2015, 1, FSO63. [CrossRef] [PubMed]

143. Saljic, A.; Jespersen, T.; Buhl, R. Anti-arrhythmic investigations in large animal models of atrial fibrillation. Br. J. Pharmacol. 2021. [CrossRef] [PubMed]

144. Nishida, K.; Michael, G.; Dobrev, D.; Nattel, S. Animal models for atrial fibrillation: Clinical insights and scientific opportunities. Europace 2009, 12, 160-172. [CrossRef]

145. Schüttler, D.; Bapat, A.; Kääb, S.; Lee, K.; Tomsits, P.; Clauss, S.; Hucker, W.J. Animal Models of Atrial Fibrillation. Circ. Res. 2020, 127, 91-110. [CrossRef] [PubMed]

146. Jost, N.; Christ, T.; Magyar, J. New Strategies for the Treatment of Atrial Fibrillation. Pharmaceuticals 2021, $14,926$. [CrossRef] [PubMed]

147. de Haan, S.; Greiser, M.; Harks, E.; Blaauw, Y.; van Hunnik, A.; Verheule, S.; Allessie, M.; Schotten, U. AVE0118, blocker of the transient outward current $\left(\mathrm{I}_{\mathrm{to}}\right)$ and ultrarapid delayed rectifier current $\left(\mathrm{I}_{\mathrm{Kur}}\right)$, fully restores atrial contractility after cardioversion of atrial fibrillation in the goat. Circulation 2006, 114, 1234-1242. [CrossRef] [PubMed]

148. Oros, A.; Volders, P.G.; Beekman, J.D.; van der Nagel, T.; Vos, M.A. Atrial-specific drug AVE0118 is free of torsades de pointes in anesthetized dogs with chronic complete atrioventricular block. Heart Rhythm 2006, 3, 1339-1345. [CrossRef] 
149. Blaauw, Y.; Schotten, U.; Van Hunnik, A.; Neuberger, H.; Allessie, M. Cardioversion of persistent atrial fibrillation by a combination of atrial specific and non-specific class III drugs in the goat. Cardiovasc. Res. 2007, 75, 89-98. [CrossRef] [PubMed]

150. Wirth, K.J.; Brendel, J.; Steinmeyer, K.; Linz, D.K.; Rütten, H.; Gögelein, H. In Vitro and In Vivo Effects of the Atrial Selective Antiarrhythmic Compound AVE1231. J. Cardiovasc. Pharmacol. 2007, 49, 197-206. [CrossRef] [PubMed]

151. Rivard, L.; Shiroshita-Takeshita, A.; Maltais, C.; Ford, J.; Pinnock, R.; Madge, D.; Nattel, S. Electrophysiological and atrial antiarrhythmic effects of a novel $\mathrm{I}_{\mathrm{Kur}} / \mathrm{Kv} 1.5$ blocker in dogs. Heart Rhythm 2005, 2, S180. [CrossRef]

152. Ford, J.; Milnes, J.; El Haou, S.; Wettwer, E.; Loose, S.; Matschke, K.; Tyl, B.; Round, P.; Ravens, U. The positive frequencydependent electrophysiological effects of the $\mathrm{I}_{\text {Kur }}$ inhibitor XEN-D0103 are desirable for the treatment of atrial fibrillation. Heart Rhythm 2016, 13, 555-564. [CrossRef]

153. Stump, G.L.; Wallace, A.A.; Regan, C.P.; Lynch, J.J. In Vivo Antiarrhythmic and Cardiac Electrophysiologic Effects of a Novel Diphenylphosphine Oxide I Kur Blocker (2-Isopropyl-5-methylcyclohexyl) Diphenylphosphine Oxide. J. Pharmacol. Exp. Ther. 2005, 315, 1362-1367. [CrossRef]

154. van Hunnik, A.; Lau, D.H.; Zeemering, S.; Kuiper, M.; Verheule, S.; Schotten, U. Antiarrhythmic effect of vernakalant in electrically remodeled goat atria is caused by slowing of conduction and prolongation of postrepolarization refractoriness. Heart Rhythm 2016, 13, 964-972. [CrossRef] [PubMed]

155. Diness, J.G.; Skibsbye, L.; Simó-Vicens, R.; Santos, J.L.; Lundegaard, P.; Citerni, C.; Sauter, D.R.P.; Bomholtz, S.H.; Svendsen, J.H.; Olesen, S.-P.; et al. Termination of Vernakalant-Resistant Atrial Fibrillation by Inhibition of Small-Conductance Ca ${ }^{2+}$-Activated $\mathrm{K}^{+}$Channels in Pigs. Circ. Arrhythmia Electrophysiol. 2017, 10, e005125. [CrossRef] [PubMed]

156. Nattel, S.; De Blasio, E.; Beatch, G.N.; Wang, W.Q. RSD1235: A novel antiarrhythmic agent with a unique electrophysiological profile that terminates AF in dogs. Eur. Heart J. 2001, 22, 448. 